\title{
The Permian-Triassic palynological transition in the Guryul Ravine section, Kashmir, India: implications for Tethyan- Gondwanan correlations
}

\author{
Rajni Tewari a,*, Ram- Awatar ${ }^{\text {a }}$, Sundeep K. Pandita ${ }^{\text {b }}$, Stephen McLoughlin ${ }^{\text {c }}$, Deepa Agnihotri a , \\ Suresh S.K. Pillai ${ }^{\text {a }}$, Vartika Singh ${ }^{\mathrm{a}}$, Kamlesh Kumar ${ }^{\mathrm{a}}$, Ghulam D. Bhat ${ }^{\mathrm{d}}$ \\ a Birbal Sahni Institute of Palaeobotany, 53 University Road, Lucknow-226007, India \\ b Department of Geology, University of Jammu, Jammu-180006, India \\ c Department of Palaeobiology, Swedish Museum of Natural History, Box 50007, S-104 05, Stockholm, Sweden \\ d Directorate of Geology and Mining, Jammu and Kashmir Government, Srinagar, India
}

\section{A R T I C L E I N F O}

\section{Article history:}

Received 2 April 2014

Accepted 23 August 2014

Available online 18 September 2014

\section{Keywords:}

Palynology

Dispersed organic matter

Permian-Triassic boundary

Guryul Ravine

India

Tethys

\begin{abstract}
A B S T R A C T
This first palynological study of the Permian-Triassic succession in the Guryul Ravine, Kashmir, India, reveals impoverished latest Permian spore-pollen assemblages in the uppermost Zewan Formation, a rich palynoassemblage from the basal Khunamuh Formation characteristic of the Permian-Triassic transition zone and depleted Triassic assemblages from higher in the Khunamuh Formation. The collective assemblages can be broadly correlated to the Densipollenites magnicorpus and Klausipollenites decipiens palynozones of peninsular India and to palynofloras spanning the Permian-Triassic boundary elsewhere in Gondwana. Generally, low spore-pollen yields and poor preservational quality of the studied assemblages hinder more precise correlations and are inferred to be a function of an offshore marine depositional setting on the margin of the Neotethys Ocean, and thermal alteration associated with Cenozoic collisional tectonism between India and Asia.
\end{abstract}

(c) 2014 Elsevier B.V. All rights reserved.

\section{Contents}

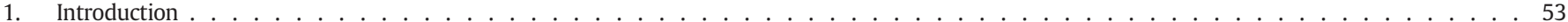

2. Previous studies . . . . . . . . . . . . . . . . . . . . . . . . . . . . . . . . . . . 54

3. Geology of the Guryul Ravine Section . . . . . . . . . . . . . . . . . . . . . . . . . . . . . . . . . . . . . . . . . . . . . . 55

4. Material and methods ... . . . . . . . . . . . . . . . . . . . . . . . . . . . . . . . . . 56

5. Palynostratigraphy . . . . . . . . . . . . . . . . . . . . . . . . . . . . . . . . . . . . . . . . . 57

5.1. Age and correlation within India . . . . . . . . . . . . . . . . . . . . . . . . . . . . . . . . . . 57

5.2. Correlation along the Indian Tethyan margin . . . . . . . . . . . . . . . . . . . . . . . . . . . . . . . . . . . . . . . . . . . . . 57

5.2.1. Correlation with the western Tethyan margin: Pakistan and Israel . . . . . . . . . . . . . . . . . . . . . . . . . 60

5.3. Correlation with core Gondwanan regions . . . . . . . . . . . . . . . . . . . . . . . . . . . . . . . . . . . . . . . . . . . . . . 60

5.4. Correlation with the Tethyan-Cathaysian region . . . . . . . . . . . . . . . . . . . . . . . . . . . . . . . . . . . . . . . . . 61

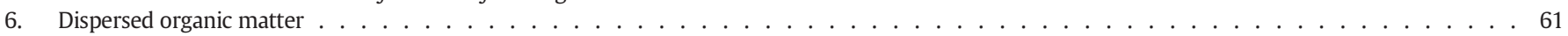

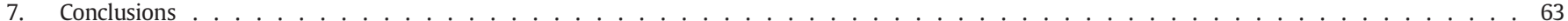

Acknowledgements . . . . . . . . . . . . . . . . . . . . . . . . . . . . . . . . . . . . . . 63

References. .63

\footnotetext{
* Corresponding author.

E-mail address: rajni_tewari@bsip.res.in (R. Tewari).
}

\section{Introduction}

The Permian-Triassic boundary (PTB) marks the greatest reduction in the diversity of life in the Phanerozoic. Terrestrial and marine faunas 
and floras were all strongly affected (Benton and Twitchett, 2003; Benton and Newell, 2014). Gondwanan floras saw the abrupt demise of the long-standing glossopterid mire communities and their replacement by vegetation dominated by peltasperms, pleuromiean lycophytes, voltzialean conifers and corystosperms (Anderson et al., 1999; Hill et al., 1999). Various possible causal mechanisms for this mass extinction have been advocated over several decades including: fluctuations in oceanic salinity (Beurlen, 1956; Stevens, 1977), pronounced excursions in temperature (either strong cooling or severe warming: Stanley, 1984, 1988; Maxwell, 1989; Retallack, 2013; Benton and Newell, 2014), ocean anoxia (Wignall and Hallam, 1992), trace element poisoning (Cloud, 1959), increased cosmic radiation (Hatfield and Camp, 1970) and a general decline in origination rates (Bakker, 1977; Hüssner, 1983). Further complicating these scenarios are conflicting interpretations of sea level change at this time, with alternatively sharp eustatic transgression or regression advocated (Newell, 1963; Maxwell, 1989; Hallam and Wignall, 1999). More recently, attention has focused on bolide impacts and emissions associated with the eruptions of large igneous provinces as driving mechanisms for global environmental change and extinction at the close of the Permian (Kaiho et al., 2001; Basu et al., 2003; Becker et al., 2004; Reichow et al., 2009) and at several other major biological crises in the Phanerozoic (Twitchett, 2006; Schulte and 40 others, 2010). Convincing evidence for a large bolide impact in the form of a pronounced and globally recognizable platinoid element anomaly or extensive shocked quartz has not been forthcoming for the end-Permian interval. In contrast, evidence for an endogenic cause for the end-Permian environmental change and biotic crisis has been steadily mounting. In particular, strong isotopic excursions across the PTB have been interpreted to represent the signature of abrupt and immense release of $\mathrm{CO}_{2}$ from Siberian trap volcanism (Hochuli et al., 2010b), potentially supplemented by release of methane from submarine clathrates (Benton and Twitchett, 2003). Such a spike in atmospheric greenhouse gases may have led to sharp and pronounced climate warming, aridification of continental interiors, and loss of standing biomass (Eshet et al., 1995; Renne et al., 1995; Knoll et al., 1996; Wignall and Twitchett, 1996; Hansen, 2006). Recovery from the initial environmental destabilization and extinctions may have been exacerbated by additional ecological crises in the Early Triassic (Retallack, 2013; Schneebeli-Hermann et al., in press).

Permian-Triassic strata in India are best known from a series of coalrich intracontinental grabens in the central and eastern subcontinent (linked to the East Gondwanan Rift System: Harrowfield et al., 2005) that host the classical 'Gondwana Series' as defined by Feistmantel (1879) and others. However, Permian and Triassic strata are also represented in extra-peninsular India. These sediments were deposited along the southern margin of the Neotethys, a semi-confined body of water separated at that time from the Palaeotethys by the Cimmerian terranes (Metcalfe 1999). These Tethyan-margin sediments are exposed in the Kashmir, Lahaul and Spiti valleys of the northwest Himalayas. The Kashmir Valley lies between two arms of the highly deformed Dhauladhar-Pir Panjal (in the south) and Zanskar (in the north) ranges. The Kashmir Valley hosts a remarkably complete CarboniferousTriassic sedimentary succession, which may have important bearings on interpreting the regional patterns of extinction and the correlation of marine and terrestrial events around the close of the Palaeozoic.

The PTB sections in the Tethyan region, are considered among the most complete and well-exposed sequences globally, as continuous sedimentation and a detailed record of low- to mid-latitude floral and faunal change are preserved there (Sheng et al., 1984). Some of the best-studied successions, including the Meishan global stratotype, occur on the isolated Cathaysian blocks along the Panthalassan margin (Shu and Utting, 1990, Peng et al., 2006) and on the similarly isolated mid-Tethyan Cimmerian terranes (Stolle, 2007), or along the northern (Laurussian) margin of the Palaeotethys (Bourquin et al., 2011).
Phytostratigraphic correlation between the core Gondwanan regions and the Tethyan-Cathaysian region has been inhibited by strong floristic provincialism in the Permian (Meyen, 1987) and in some cases by inadequate quality of palynomorph preservation (Shu and Utting, 1990, Peng et al., 2006).

Along the Tethyan margin of Gondwana, the most intense palynostratigraphic research on the PTB has focused on the nearpalaeoequatorial extreme northern limit of Gondwana in modern Israel (Eshet and Cousminer, 1986; Eshet, 1992) and on the Salt Range succession in Pakistan (see Schneebeli-Hermann et al. 2014, and references therein). Palynostratigraphic studies of the PTB sequences further east have been more sporadic, even though these successions locally host biostratigraphically important invertebrate fossil assemblages. In particular, the Permo-Triassic section at Guryul Ravine (Kashmir), on the southern margin of the Neotethys, has been considered a contender for the global stratotype section. However, the precise position of the PTB in this region has long been debated (Erwin, 1993; Yin et al., 2001; Brookfield et al., 2010).

At Guryul Ravine, the Lopingian (Upper Permian) Zewan Formation is overlain by the Lower Triassic Khunamuh Formation in a $>100-\mathrm{m}$ thick conformable succession. Here we present the results of a reconnaissance palynological study of outcrop samples recovered from the classical uppermost Permian and lowermost Triassic succession at Guryul Ravine, which was logged in fine sedimentological detail. We aim to test whether palynology has the potential to refine the position of the Permian-Triassic boundary within this succession and evaluate the palaeofloristic signal and depositional setting for the mid-latitude southern margin of the Neotethys at this time.

\section{Previous studies}

The stratigraphy of the Kashmir Himalayas has a complex nomenclatural history. The first stratigraphic scheme established by Lydekker (1883) divided the Palaeozoic rocks into the "Metamorphic", Panjal and Zanskar systems. Hayden (1907) and Middlemiss (1909) recorded diagnostic Permian Gondwanan (Gangamopteris and Glossopteris) plant fossils immediately below the marine strata of the Zewan Formation. Later, Middlemiss (1910) outlined the general stratigraphy and palaeontology of the Kashmir region and subdivided the SilurianTriassic rocks into a mix of formal and informal litho- and chronostratigraphic units, namely the "Older Silurian”, “Upper Silurian”, Muth Quartzite, "Syringothyris Limestone", Passage Beds, "Fenestella Series", "Agglomeratic Slates", "Panjal Volcanic Flow", “Gangamopteris beds", Zewan beds, "Lower Triassic", "Muschelkalk" and "Upper Triassic". On the basis of plant fossil assemblages, Kapoor $(1977,1979)$ divided the Permian strata of Kashmir into the Nishatbagh, Vihi, Marahoma, Munda and Mamal beds. Ahmad et al. (1978) and Singh et al. (1982) distinguished the plant-fossil-bearing beds below the Panjal Traps as the Nishatbagh Formation and those above the Panjal Traps as the Mamal Formation.

Other studies have focused on disparate aspects of the palaeontology and geochemistry of these successions. Nakazawa (1977, 1992), Nakazawa et al. (1970), Sweet (1970), Teichert et al. (1970), Nakazawa and Kapoor (1977, 1981), Matsuda (1981a, 1983, 1984), Furnish et al. (1973) and Okimura and Ishii (1981) have reported various conodonts, gastropods, bivalves, ammonoids (Cyclolobus walkeri) and foraminifers from the Guryul Ravine strata. Recently, Brookfield et al. (2003) and Algeo et al. (2007) sampled exposures in this area, assessing the concentrations of rare and trace elements, total organic carbon - total inorganic carbon (TOC-TIC), and organic $\delta^{13} \mathrm{C}-\delta{ }^{15} \mathrm{C}$ signatures to evaluate climate change across the PTB. Additionally, Brookfield et al. (2010) carried out an analysis of platinum group elements from the Upper Permian Section at Guryul Ravine but they did not detect a significant extraterrestrial signal in their results. Brookfield (1993) and Brookfield et al. (2010) also detailed the palaeogeographic evolution of the Kashmir region during late Palaeozoic. 
Palynological studies of this region have been hindered by manifold problems, most notably: difficulties in obtaining access to this politically sensitive area, pronounced topographic relief rendering access physically difficult, and strong shearing and thermal maturity of the Palaeozoic and Mesozoic strata related to the affects of Cenozoic collisional tectonics between India and Asia. Palynofloras from the Permian and Triassic successions of the Kashmir Himalayas are sparse and commonly ill-preserved, and this detracts from their application for accurate correlation with continental successions preserved further south in peninsular India. Nevertheless, some palynological data has been forthcoming from this region. Nautiyal and Sahni (1976) recorded the bisaccate pollen Platysaccus papilionis, Klausipollenites decipiens and Sulcatisporites sahnii in association with various species of Leiosphaeridia and Tasmanites from the Lower Triassic argillaceous sequence at Pahalgam, $50 \mathrm{~km}$ east of Srinagar. Subsequently, Maheshwari et al. (1996) reported Early Permian palynomorphs (viz., Cordaitina, Potonieisporites, Densipollenites, Striomonosaccites, Scheuringipollenites, Cedripites, Protohaploxypinus, Striatites, Lahirites, Gondwanipollenites, Rhizomaspora and Schizopollis species) from the Dunpatheri Member of the Mamal Formation in this area. Here we present the first palynological data from the Upper Permian to Lower Triassic succession of the Guryul Ravine, and outline the difficulties, but also the future potential for improved palynostratigraphic correlation in this region.

\section{Geology of the Guryul Ravine Section}

The Guryul Ravine Section (Fig. 1) lies c. 13 km southeast of Srinagar in Jammu and Kashmir State (Fig. 2). It is approachable through the village of Khunamuh, which is well connected to Srinagar by a paved road. The Permian-Triassic Section in the Guryul Ravine incorporates the Upper Permian Zewan and the Lower Triassic Khunamuh formations both marine units. This succession was deposited in a passive-margin setting following the Permian rifting and basaltic volcanism associated with separation of a Cimmerian microcontinent from the northern flank of Gondwana (Fig. 3; Sengör, 1984; Brookfield, 1993).

The Zewan Formation is $97.3 \mathrm{~m}$ thick and is divided into four informal members, named A to D; and the Khunamuh Formation is divided into six informal members, named $\mathrm{E}$ to $\mathrm{J}$ in ascending order, on the basis of variation in carbonate content (generally increasing carbonate up section: Fig. 4; Algeo et al., 2007). Although carbonate rocks are an essential component of Member A of the Zewan Formation, these are locally intermixed with sandy shales. Member B, comprises shale intermixed with carbonate mudstones. Member $\mathrm{C}$ is represented mainly by rhythmic alternations of calcareous sandstones and sandy shales, of which, the latter are dominant. Member D is characterized mainly by thick-bedded sandy limestones and calcareous sandstones representing shallow marine facies. Members C and D of the Zewan Formation are characterized by the predominance of gastropods and bivalves, whereas brachiopods are scarce (Korte et al., 2010).

The succeeding Khunamuh Formation contrasts strongly in lithology with the Zewan Formation, but no unconformity has been observed between these formations (Kapoor, 1977; Sheng et al., 1984; Yin, 1993). Member E of the Khunamuh Formation consists of alternating shale and subordinate limestone. It is informally divided into units $E_{1}, E_{2}$ and $E_{3}$ on the basis of varying proportions of shale. Unit $E_{1}$ is $2.6 \mathrm{~m}$ thick and consists of dark grey to black shale intercalated with several thin limestone layers. Of stratigraphic significance, the first appearance datum (FAD) of the basal Triassic conodont marker species, Hindeodus parvus (or possibly $H$. preparvus) and the FADs of six typically Triassic ammonoid taxa, were detected about $1 \mathrm{~m}$ above the base of unit $\mathrm{E}_{2}$ (Fig. 4) but dwarf shelly fossils characteristic of the PTB occur in beds 47-49 of this succession, i.e., within unit $\mathrm{E}_{1}$ (Brookfield et al., 2003, 2010). The main fossil constituents of unit $E_{1}$, besides typical Triassic elements, include Permian conodonts, viz., Clarkina carinata, Hindeodus typicalis and Ellisonia triassica, brachiopods (Linoproductus sp. cf. L. lineatus, Dialesma? sp.) and abundant bivalves, viz., Palaeolima middlemissii, Etheripecten sp. aff. E. haydeni and Cyrtorostra sp. aff. C. lunwalensis (Sweet, 1970; Nakazawa et al., 1975; Matsuda, 1981a, 1981b; Murata, 1981). Bivalves are more abundant than brachiopods in this unit. Among the bivalves, Claraia bioni Nakazawa, a common component of Early Triassic faunas, is present throughout member $\mathrm{E}$. Further, Claraia bioni is morphologically similar to the characteristic Triassic genus Peribositra (Sheng et al., 1984). Thus, unit $\mathrm{E}_{1}$ contains a mix of typical Permian and Triassic marine faunal elements (Nakazawa et al., 1970; Teichert et al., 1970; Kapoor, 1996). Further, Algeo et al. (2007) noted two short-lived negative C-isotope excursions in the uppermost Zewan Formation, prior to a large (c. -4.0 to $-4.5 \%$ ) and sustained negative excursion commencing at the Zewan-Khunamuh formation contact (see also Baud et al., 1996), which they interpreted to coincide roughly with the end-Permian extinction event shortly before the PTB proper.

Unit $E_{2}$ is $6.1 \mathrm{~m}$ thick and comprises black to dark grey, rarely greenish shales intercalated with dark limestones yielding ammonoids (including Otoceras woodwardi) and other marine fossils. Unit $\mathrm{E}_{3}$ is $9.9 \mathrm{~m}$ thick and is of similar lithology, comprising black shales intercalated with limestones but the shale in this unit is less fissile. The only macrofossil taxon recovered from this unit is Ophiceras. Member F is 5-10 m thick and composed mainly of alternating shales and limestones, whereas member G comprises mostly limestone with a thin shale package. Member $\mathrm{H}$ represents shales and limestones together with calcareous or muddy sandstone.

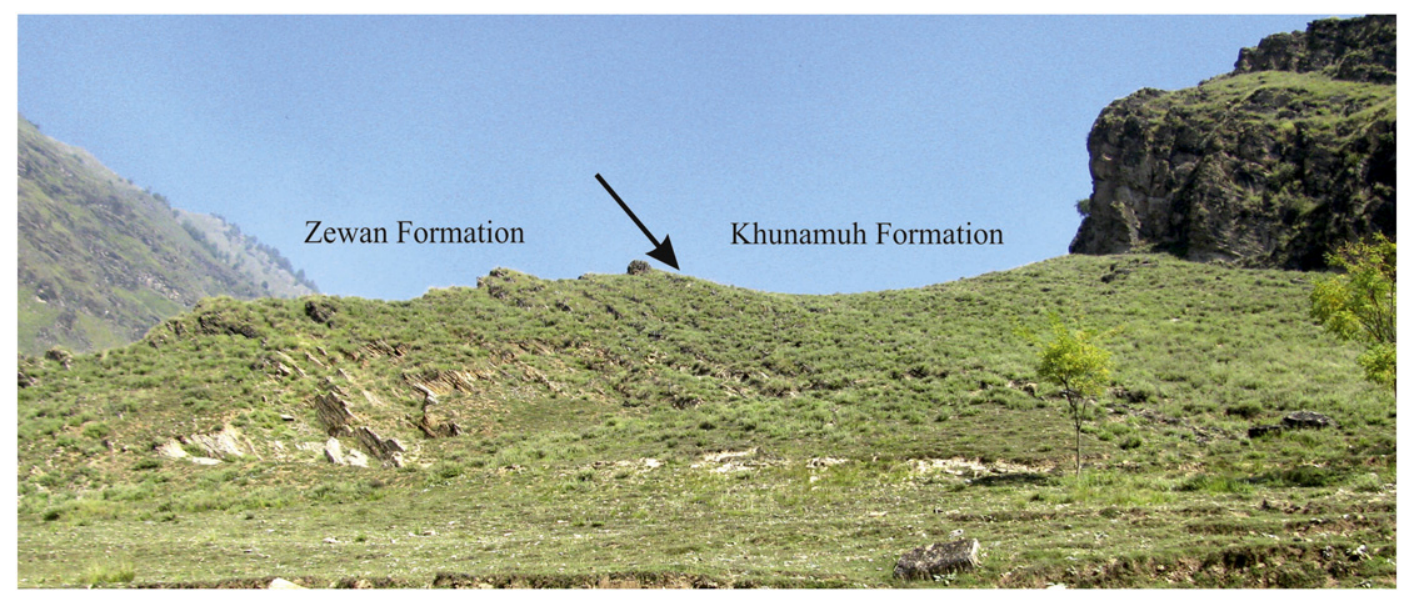

Fig. 1. Field photograph of the Guryul Ravine showing the Zewan Formation(Upper Permian) to Khunamuh Formation(Lower Triassic) boundary (marked by arrow). 


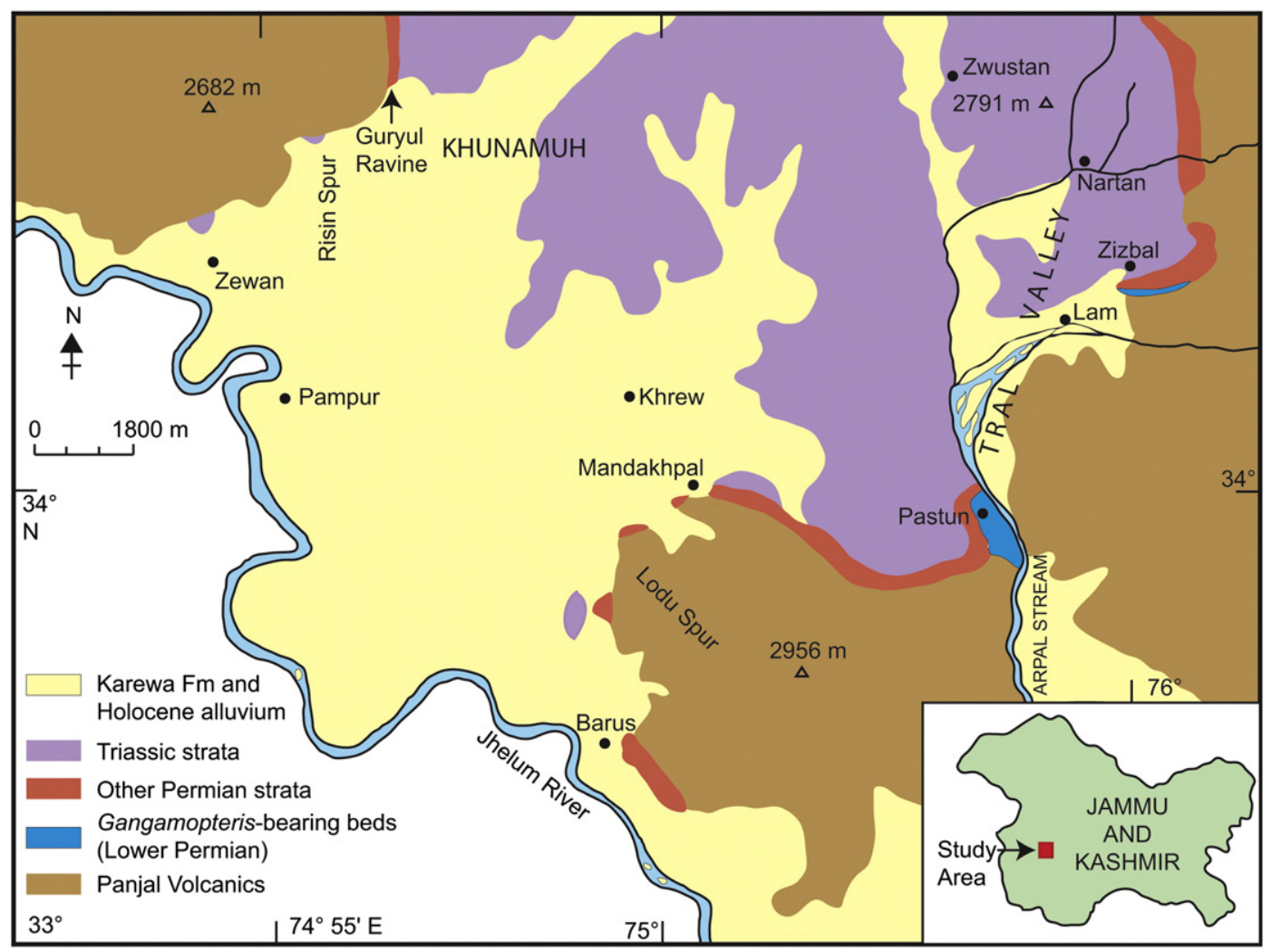

Fig. 2. Geological map of the study area in Kashmir, India. Modified from Bhat and Bhat (1997).

Member I is a 10-30 cm thick limestone unit and Member J consists of muddy calcareous sandstones alternating with thin shale bands (Kapoor, 1996). Nakazawa et al. (1970) and Kapoor (1996) provided further lithological details of the various members of the Zewan and Khunamuh formations.

\section{Material and methods}

During two field trips undertaken in 2011 and 2012 to various parts of Kashmir, nine samples (GR1 to GR9; Fig. 4) were collected from the Permian and Triassic section of Guryul Ravine for a reconnaissance

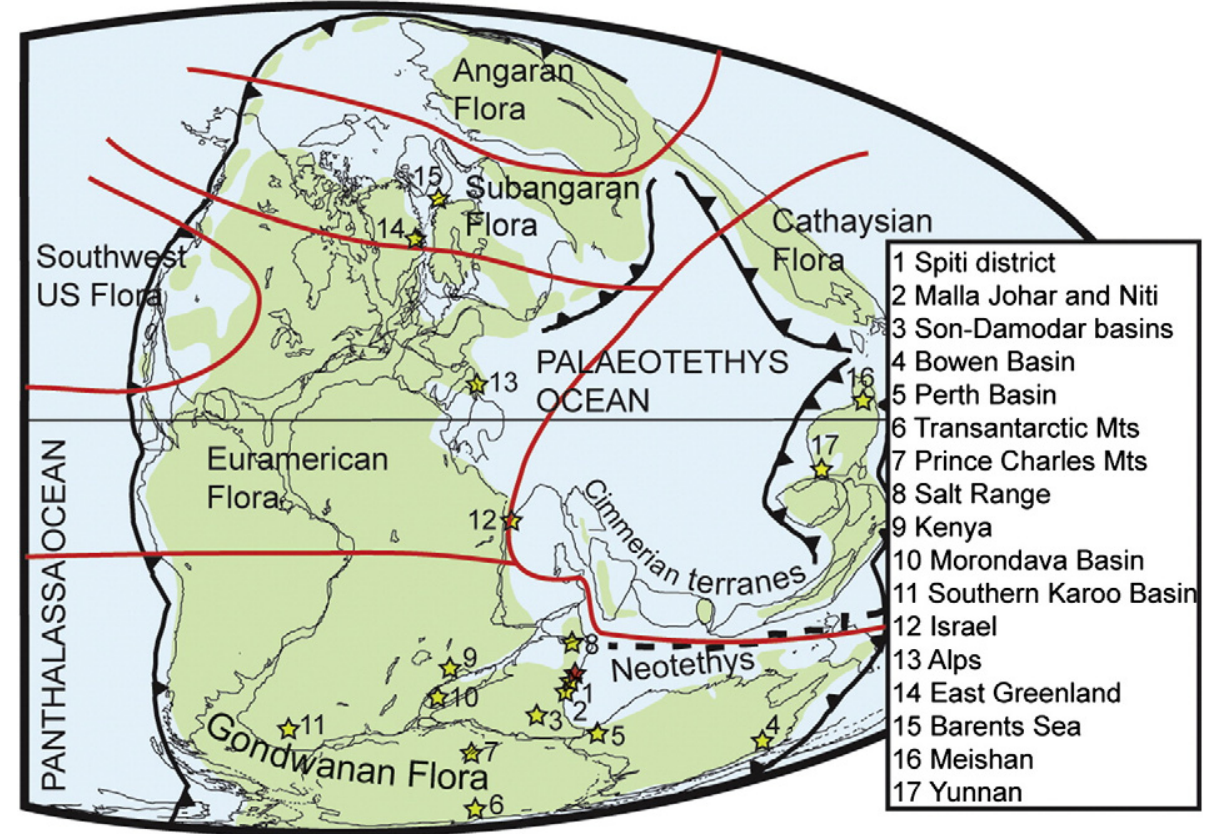

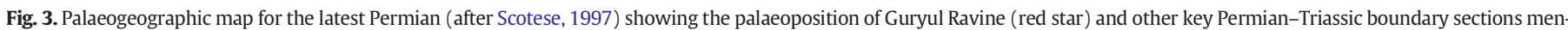
tioned in the text studied for palynology (yellow stars). Red lines indicate the approximate positions of the major palaeofloristic provinces. 
survey of the palynofloras. Although organic matter was recovered from all samples, only six yielded fossil spores and pollen. Of these, GR1 from the base, GR2 from the middle and GR3 from the top of the sandy shale (bed 31) of member C, and GR4 from the top of the argillaceous sandstone package (bed 45) of member D were collected from the Zewan Formation. GR2 and GR4 yielded sparse but well-preserved spores and pollen. GR5 and GR6 were collected from the 'mixed zone', i.e., unit $\mathrm{E}_{1}$. GR5 was collected from $120 \mathrm{~cm}$ above the base of that unit and GR6 from the top of this package. Whereas only a single identifiable spore taxon was recovered from GR5, sample GR6 yielded a rich palynological assemblage. A few algal spores were recovered from GR7 collected from the shale package $30 \mathrm{~cm}$ above the base of unit $E_{2}$ and sparse spores and pollen grains from GR8 collected from the uppermost limestone bed of unit $\mathrm{E}_{2}$. Sample GR9 collected from the shale $50 \mathrm{~cm}$ above the base of member $E_{3}$ yielded only unidentifiable organic matter. Because most samples yielded less than 300 specimens, we refrained from undertaking formal quantitative evaluations of the spore-pollen assemblages. The palynological samples studied here were prepared by crushing the rock followed by hydrochloric acid (40\%) and hydrofluoric acid (35\%) treatments. Subsequently, residues were washed thoroughly with water, oxidized using Schulze's solution and passed through a $400 \mu \mathrm{m}$ sieve. A few drops of the organic residue mixed with polyvinyl alcohol were spread on the slides. The residues were dried, mounted under a coverslip in canada balsam, and studied using a Leica DM 3000 light microscope. Samples used for the study of dispersed organic matter were treated with hydrochloric and hydrofluoric acids for the removal of carbonate and silica, respectively. The organic matter was cleaned with distilled water after each acid treatment, sieved using a 20-micron mesh, mixed with polyvinyl alcohol and mounted in canada balsam on microscope slides for quantitative evaluation of dispersed organic matter content using a transmitted light microscope. The categorization and quantification of organic matter was based on visual estimation of components in individual mounted residues. Various schemes for the classification of dispersed organic matter have been published (Combaz, 1964; Alpern, 1970; Masran and Pocock, 1981; Robert, 1981; Habib, 1982; Batten, 1983; Hart, 1986; van Bergen et al. 1990; Boussafir et al., 1995; Tyson, 1995); we use the scheme of Ercegovac and Kostic (2006) since it provides a simple means of categorizing organic matter and correlates dispersed organic components with coal macerals. Slides are deposited in the repository of the Birbal Sahni Institute of Palaeobotany (BSIP), Lucknow. Reference positions of specimens on these slides are provided in terms of either England Finder coordinates or stage coordinates of the Leica DM 3000 light microscope, BSIP.

\section{Palynostratigraphy}

\subsection{Age and correlation within India}

We recorded 33 spore-pollen taxa (Table 1), in addition to unidentified algae, fungal spores and wood fragments, from the Zewan and Khunamuh formations (Fig. 4). Only five taxa were recorded from the Zewan Formation (Fig. 4R, U, X, Y, Z): the non-taeniate bisaccate pollen Alisporites sp., and the taeniate bisaccate pollen Lunatisporites gopadensis and Crescentipollenites fuscus (in Member C), together with the trilete spore Verrucosisporites sp. and the taeniate bisaccate pollen Protohaploxypinus sp. (in Member D). This impoverised palynoflora containing taxa that are, in most cases, not strongly age diagnostic, prevents confident correlation or precise age determination of the Zewan Formation. However, the recorded taxa are broadly consistent with a Middle or Late Permian age because Protohaploxypinus pollen have been consistently recovered from glossopterid sporangia (Lindström et al., 1997, and references therein).

Within the Khunamuh Formation, 19 genera and 27 distinguishable species and morphotypes were recorded from Unit $\mathrm{E}_{1}$. Trilete spores are represented by seven genera, monosaccate pollen by four genera, taeniate bisaccate pollen by two genera, striate-bisaccates by three genera, non-bisaccate pollen by two genera and alete spores by a single genus (Fig. 4A-E, G-P, S, T, V, W). Fungal spores (Fig. 5A-C) are also present. The unit $\mathrm{E}_{1}$ palynoassemblage is numerically dominated by taeniate bisaccate pollen followed by trilete spores, monosaccate pollen, non-taeniate bisaccate pollen, then other pollen and fungal spores that collectively represent a mix of taxa with typical Late Permian and Early Triassic ranges. The unit $\mathrm{E}_{1}$ palynotaxa are shared with both the Densipollenites magnicorpus Assemblage Zone and the Klausipollenites decipiens Assemblage Zone defined in the Permo-Triassic successions of peninsular India (Tiwari and Tripathi, 1992).

Characteristics shared with the Densipollenites magnicorpus Assemblage Zone include abundant taeniate bisaccate pollen (Protohaploxypinus and Striatopodocarpites species) and less abundant representation of Crescentipollenites, Striatopiceites and Horriditriletes species. The Densipollenites magnicorpus Assemblage Zone is represented in the Upper Permian Raniganj Formation of the Damodar Valley region (Tiwari et al., 1984; Tiwari and Singh, 1986; Tiwari and Tripathi, 1992; Tiwari and Vijaya, 1992, 1994; Tiwari, 1999; Tripathi et al. 2005). Associations of Crescentipollenites and Protohaploxypinus species equivalent to those represented in units $C$ and $D$ of the Zewan Formation also occur in the Upper Permian of the Mahanadi and South Rewa Gondwana basins and Godavari Graben (Tripathi, 2001; Ram-Awatar, 1993; Jha and Aggarwal, 2012; Jha et al., 2012).

Elements shared with the Klausipollenites decipiens Assemblage Zone include species of Goubinispora, Kamthisaccites, Playfordiaspora, Limatulasporites, Klausipollenites and Alisporites. This assemblage zone is represented in the lower Panchet Formation of the Damodar Valley region and in equivalent strata further to the south (Jha and Aggarwal, 2012). This zone is considered to be of Early Triassic (Induan) age based on the occurrence of key taxa, such as Playfordiaspora cancellosa, Lunatisporites diffusus and Lundbladispora microconata (Tiwari et al., 1984; Tiwari and Singh, 1986; Tiwari and Tripathi, 1992; Tiwari and Vijaya, 1994), although a very latest Permian age is also possible based on the stratigraphic distribution of glossopterids (McLoughlin, 2011; Schneebeli-Hermann et al., in press). Species of Densipollenites, Lunatisporites and Lundbladispora are represented in both of the aforementioned assemblage zones in peninsular India. Collectively, the known ranges of taxa represented in unit $E_{1}$ indicate an age very close to the PTB.

Unit $E_{2}$ of the Khunamuh Formation yielded only four spore-pollen taxa (Fig. 4H, J, L, M) namely, Taeniaesporites sp. (taeniate bisaccate pollen), Scheuringipollenites barakarensis (non-striate bisaccate pollen), Densipollenites magnicorpus (monosaccate pollen) and Cingulitriletes sp. (trilete spore). Although weakly age-diagnostic, the previously reported distribution of these taxa is consistent with an Early Triassic age (Tiwari and Vijaya 1992; Tripathi et al., 2005). Other fossils recorded from this unit include algal spores (Fig. 5D, E), alete spores (Fig. 5G) and gymnosperm tracheids (Fig. 5F) but these are not age diagnostic.

\subsection{Correlation along the Indian Tethyan margin}

Late Permian and Early Triassic palynoassemblages have been recovered from various sites along the Tethyan margin of the Indian subcontinent including Malla Johar (Tiwari et al., 1980) and Niti (Tiwari et al., 1996) in Uttarakhand, the Spiti district of Himachal Pradesh (Singh et al., 1995; Ram-Awatar, 2011) and the Salt Range, Pakistan (Balme, 1970; Schneebeli-Hermann et al. in press). Early Triassic palynomorphs have also been recorded from the Pahalgam area in Kashmir (Nautiyal and Sahni, 1976).

The occurrence of Crescentipollenites in the upper part of unit $\mathrm{C}$ and Protohaploxypinus in unit D favours tentative correlation of the Zewan Formation with Late Permian palynoassemblages of the Kuling Shale of Niti Pass, the Raulibagar sections of the Niti area (Tiwari et al., 1996) and strata exposed in the Malla Johar area (Tiwari et al., 1980) along the Tethyan margin of India. A similar association of Crescentipollenites, 
Lunatisporites and Protohaploxypinus species is represented in the Late Permian Chhidru Formation of the Salt Range, Pakistan (Balme, 1970; Schneebeli-Hermann et al. in press).
The palynoassemblages from unit $\mathrm{E}_{1}$ of the Khunamuh Formation at Guryul Ravine share abundant Protohaploxypinus, Srtiatopodocarpites and Crescentipollenites and less common Densipollenites and Goubinispora

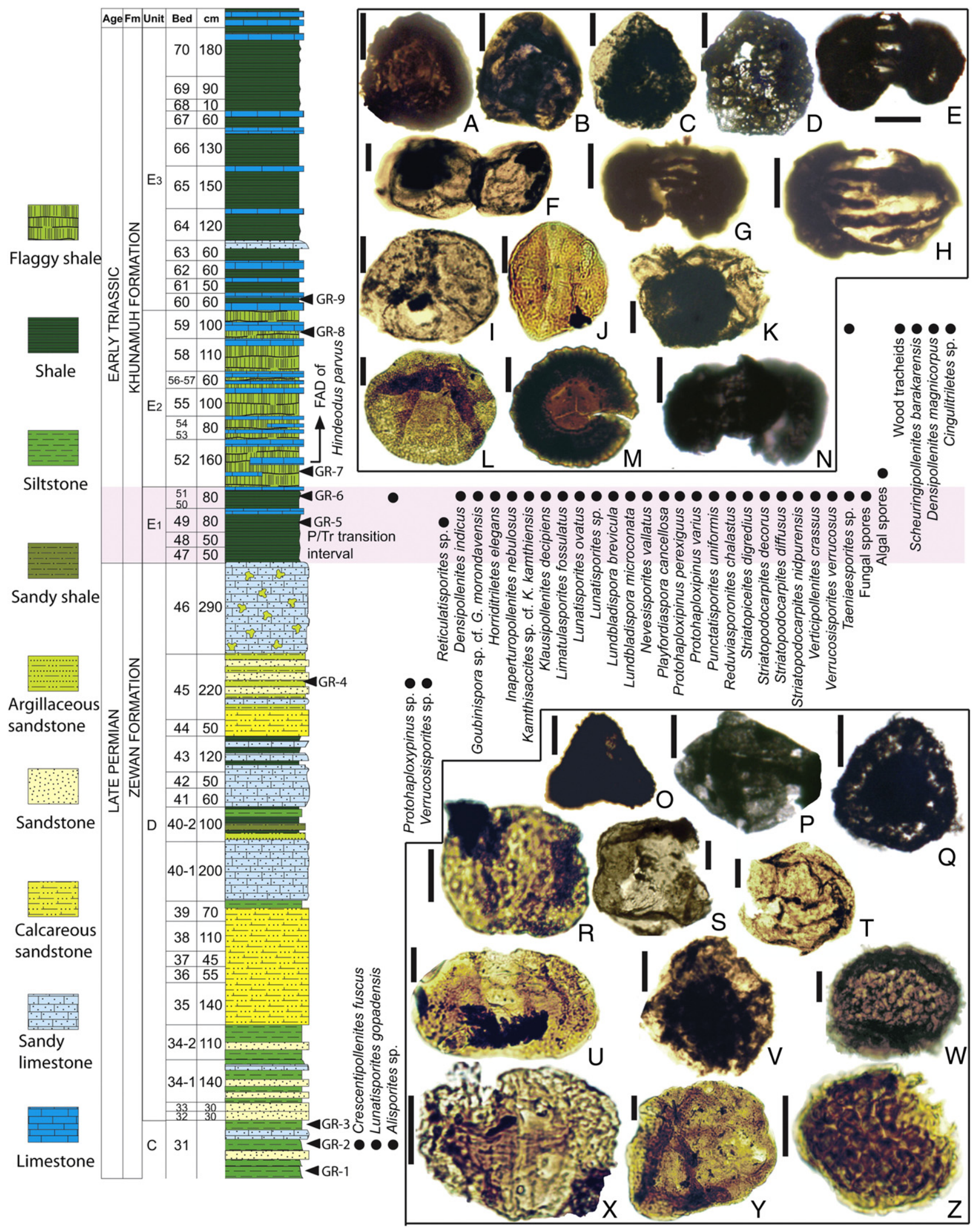


Table 1

Chart showing the distribution of palynotaxa in Upper Permian and Lower Triassic samples from the Guryul Ravine Section, Kashmir.

\begin{tabular}{|c|c|c|c|c|c|c|c|c|c|}
\hline \multirow[t]{4}{*}{ Palynotaxa } & \multirow{2}{*}{\multicolumn{4}{|c|}{ Zewan Formation(Upper Permian) }} & \multicolumn{5}{|c|}{ Khunamuh Formation(Lower Triassic) } \\
\hline & & & & & \multicolumn{5}{|c|}{ Member E } \\
\hline & \multicolumn{3}{|c|}{ Member C } & \multirow{2}{*}{$\frac{\text { Member D }}{\text { GR-4 }}$} & \multicolumn{2}{|c|}{ Unit $E_{1}$} & \multicolumn{2}{|c|}{ Unit $\mathrm{E}_{2}$} & \multirow{2}{*}{$\frac{\text { Unit } E_{3}}{\text { GR-9 }}$} \\
\hline & GR-1 & GR-2 & GR-3 & & GR-5 & GR-6 & GR-7 & GR-8 & \\
\hline Alisporites sp. & - & $*$ & - & - & - & * & - & - & - \\
\hline Crescentipollenites fuscus & - & * & - & - & - & - & - & - & - \\
\hline Lunatisporites gopadensis & - & $*$ & - & - & - & - & - & - & - \\
\hline Protohaploxypinus sp. & - & - & - & $*$ & - & - & - & - & - \\
\hline Verrucosisporites sp. & - & - & - & * & - & - & - & - & - \\
\hline Reticulatisporites sp. & - & - & - & - & $*$ & - & - & - & - \\
\hline Densipollenites indicus & - & - & - & - & - & $*$ & - & - & - \\
\hline Goubinispora sp. cf. G. morondavensis & - & - & - & - & - & * & - & - & - \\
\hline Horriditriletes elegans & - & - & - & - & - & * & - & - & - \\
\hline Inaperturopollenites nebulosus & - & - & - & - & - & $*$ & - & - & - \\
\hline Kamthisaccites sp. cf. K. kamthiensis & - & - & - & - & - & * & - & - & - \\
\hline Klausipollenites decipiens & - & - & - & - & - & $*$ & - & - & - \\
\hline Limatulasporites fossulatus & - & - & - & - & - & $*$ & - & - & - \\
\hline Lunatisporites ovatus & - & - & - & - & - & * & - & - & - \\
\hline Lunatisporites sp. & - & - & - & - & - & * & - & - & - \\
\hline Lundbladispora brevicula & - & - & - & - & - & $*$ & - & - & - \\
\hline Lundbladispora microconata & - & - & - & - & - & $*$ & - & - & - \\
\hline Nevesisporites vallatus & - & - & - & - & - & $*$ & - & - & - \\
\hline Playfordiaspora cancellosa & - & - & - & - & - & $*$ & - & - & - \\
\hline Protohaploxypinus perexiguus & - & - & - & - & - & $*$ & - & - & - \\
\hline Protohaploxypinus varius & - & - & - & - & - & $*$ & - & - & - \\
\hline Punctatisporites uniformis & - & - & - & - & - & $*$ & - & - & - \\
\hline Reduviasporonites chalastus & - & - & - & - & - & $*$ & - & - & - \\
\hline Striatopiceites digredius & - & - & - & - & - & $*$ & - & - & - \\
\hline Striatopodocarpites decorus & - & - & - & - & - & $*$ & - & - & - \\
\hline Striatopodocarpites diffusus & - & - & - & - & - & $*$ & - & - & - \\
\hline Striatopodocarpites nidpurensis & - & - & - & - & - & * & - & - & - \\
\hline Verticipollenites crassus & - & - & - & - & - & $*$ & - & - & - \\
\hline Verrucosisporites verrucosus & - & - & - & - & - & $*$ & - & - & - \\
\hline Taeniaesporites sp. & - & - & - & - & - & * & - & * & - \\
\hline Cingulitriletes sp. & - & - & - & - & - & - & - & * & - \\
\hline Densipollenites magnicorpus & - & - & - & - & - & - & - & * & - \\
\hline Scheuringipollenites barakarensis & - & - & - & - & - & - & - & * & - \\
\hline
\end{tabular}

species with the latest Permian-Early Triassic palynoflora of the Gungri Formation and Lilang Group of the Niti Area and Spiti Valley (Tiwari et al., 1996; Singh et al., 1995; Tiwari, 1997; Ram-Awatar, 2011). The younger beds of the Lingti Road Section in the Niti Area, i.e., within the basal part of Lilang Group yield Playfordiaspora, Goubinispora, Lundbladispora, Lunatisporites, Kamthisaccites and Klausipollenites species of distinctly Early Triassic age. These correlations favour the placement of unit $\mathrm{E}_{1}$ of the Khunamuh Formation very close to the PTB.

The collective Zewan and lower Khunamuh Formation palynoassemblages can also be broadly correlated with those of the Kuling Shale from the Hotigad and Shal-Shal Nala sections, Niti
Area, based on a similar representation of the StriatopodocarpitesCrescentipollenites complex in association with Densipollenites, Klausipollenites, Protohaploxypinus and Lunatisporites species. The Rambakot Member of the Shal-Shal Formation in these same sections, c. $2.25 \mathrm{~m}$ above the PTB, contains other taxa characteristic of unit $\mathrm{E}_{1}$ : Playfordiaspora, Goubinispora, Lundbladispora, Lunatisporites and Klausipollenites species. Although the Early Triassic palynoflora from the Pahalgam area, Kashmir, is dominated by acritarchs and prasinophycean cysts, the presence of Klausipollenites decipiens, Platysaccus sp. cf. P. papilionis and Sulcatisporites sahnii (Nautiyal and Sahni, 1976) and some striate bisaccate pollen suggests a similar age to the basal Khunamuh Formation.

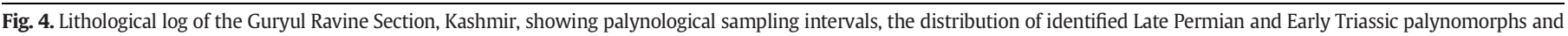

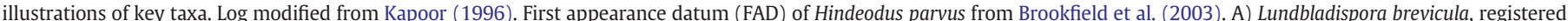

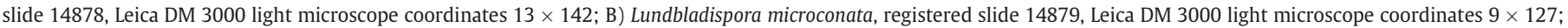

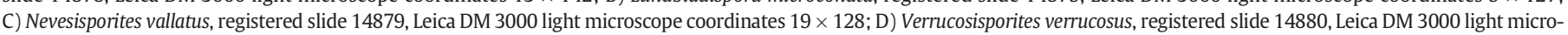

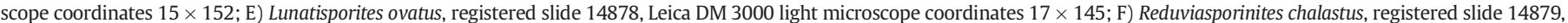

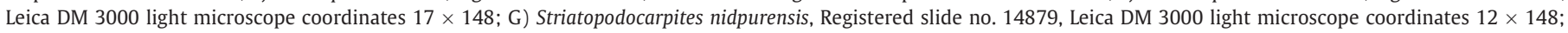

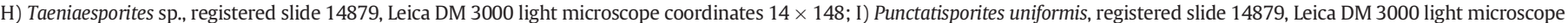

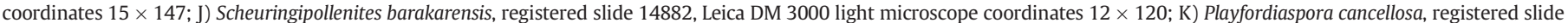

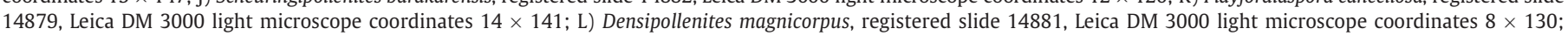

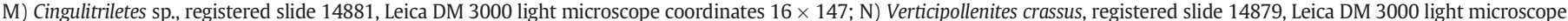

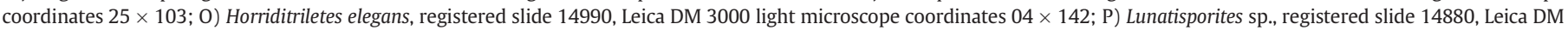

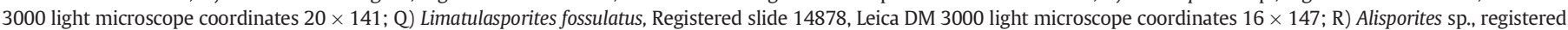

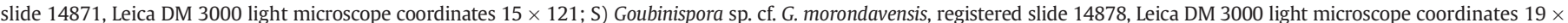

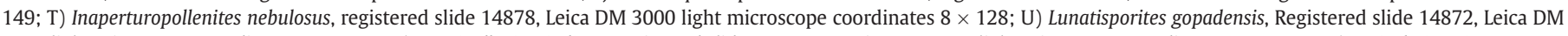

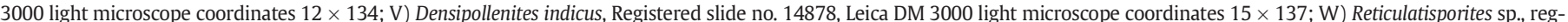

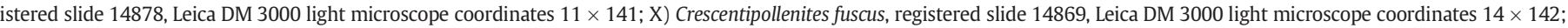

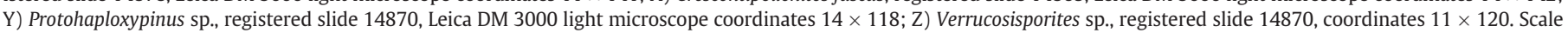
bars: $20 \mu \mathrm{m}$. 


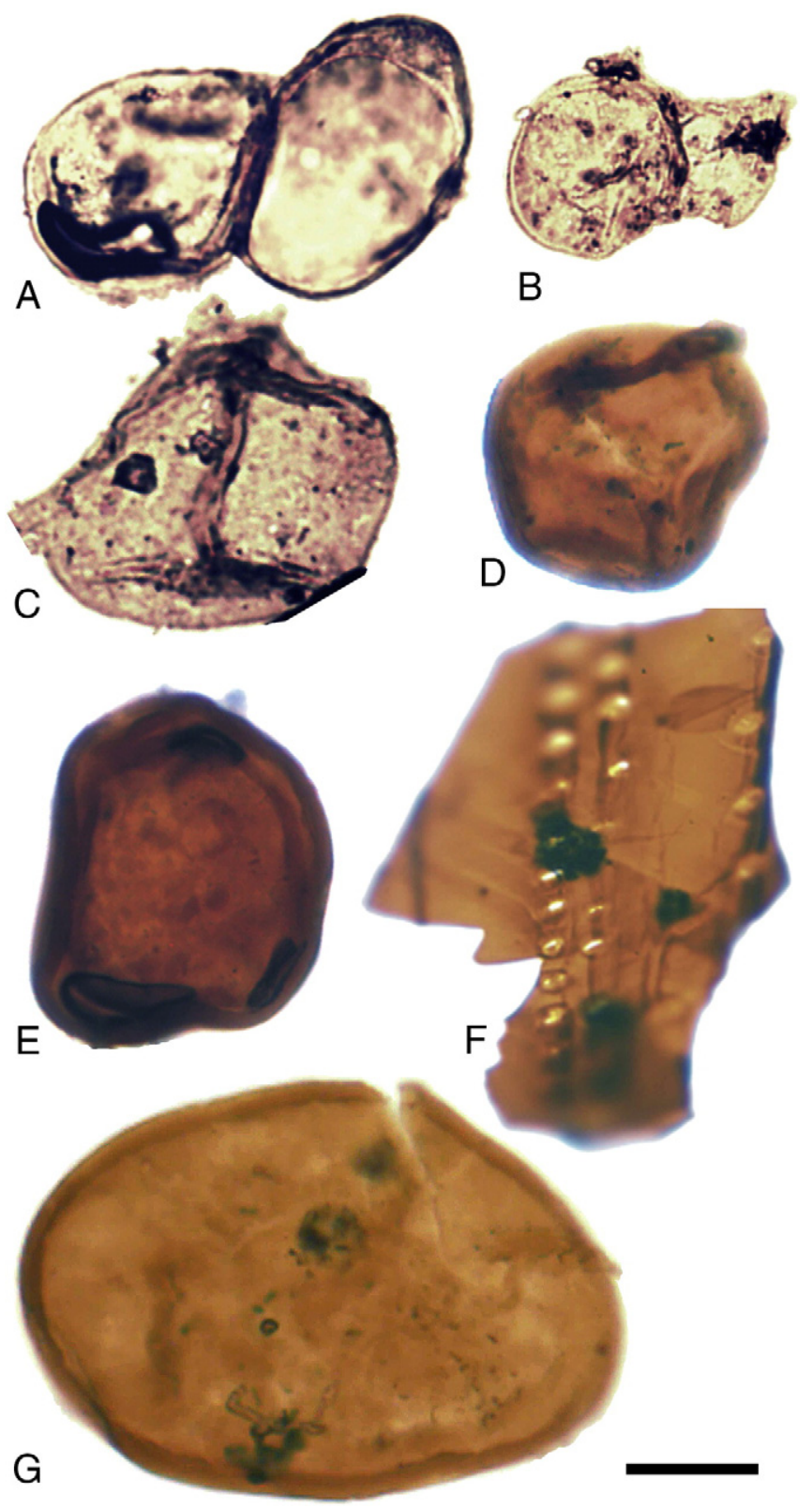

Fig. 5. Selected palynomorphs from unit $E_{1}$ of the Khunamuh Formation. A) Fungal spore, registered slide 14873, Leica DM 3000 light microscope coordinates $05 \times 134$; B) Fungal spore, registered slide 14874, Leica DM 3000 light microscope coordinates $11 \times 132$; C) Fungal spore, registered slide 14874, Leica DM 3000 light microscope coordinates $05 \times 132$; D) Algal spore, registered slide 14875, Leica DM 3000 light microscope coordinates $13 \times 123$; E) Algal spore, registered slide 14875, Leica DM 3000 light microscope coordinates $18 \times 126 ;$ F) Wood tracheid, registered slide no. 14877, Leica DM 3000 light microscope coordinates $18 \times 155$; G) Alete spore/cyst, registered slide 14876, Leica DM 3000 light microscope coordinates $10 \times 133$. Scale bars: $25 \mu \mathrm{m}$.

\subsubsection{Correlation with the western Tethyan margin: Pakistan and Israel}

The uppermost Permian and lowermost Triassic successions in the Salt Range are represented by the Chhidru and Mianwali formations, respectively (Balme, 1970). Late Permian palynoassemblages of the Chhidru Formation contain abundant striate bisaccate pollen (especially Protohaploxypinus and Striatopodocarpites) - a feature in common with the Zewan and lowermost Khunamuh formations (Balme, 1970; Schneebeli-Hermann et al. in press). Earliest Triassic palynofloras from the Mianwali Formation (Kathwai Member) recorded by Balme (1970) contain Playfordiaspora, Densipollenites, Goubinispora, Lundbladispora and Klausipollenites species in common with unit $\mathrm{E}_{1}$ of the Khunamuh Formation, further supporting the dating of this unit close to the PTB.
Early Triassic palynoassemblages from the Makhtesh Quatan 2 well, northern Negev, southern Israel, contain marine acritarchs (Veryhachium spp. and Micrhystridium spp.) in association with Endosporites papillatus, Krauselisporites spp. and Lunatisporites noviaulensis (Eshet and Cousminer, 1986; Eshet, 1992). Although this low-latitude palynoflora shares fewer taxa with the Guryul Ravine succession than other Gondwanan regions do, the shared occurrence of Lunatisporites with unit $\mathrm{E}_{1}$ offers potential for improved trans-latitudinal correlation in the future when intervening regions are sampled and when improved consistency is achieved in the taxonomic subdivision of this genus by workers from separate regions. Significantly, the presence of the 'disaster species' Reduviasporonites chalastus (Fig. 4F) in both sections confirms an age close to the endPermian mass extinction event (Eshet et al., 1995; Afonin et al., 2001; Foster et al., 2002).

\subsection{Correlation with core Gondwanan regions}

Amongst the core regions of Gondwana beyond India, the palynostratigraphy of Permian-Triassic transitional successions has been studied extensively from Australia (Foster, 1979, 1982, 1983; Helby et al., 1987; Backhouse, 1991), Antarctica (Kyle, 1977; Kyle and Schopf, 1982; Farabee et al., 1990, 1991; Lindström, 1995; McLoughlin et al., 1997; Collinson et al., 2006; Lindström and McLoughlin, 2007), Madagascar (Wright and Askin, 1987), South Africa (Steiner et al., 2003), and East Africa (Hankel, 1992).

The impoverished unit $C$ and $D$ assemblages of the Zewan Formation are broadly similar to most Middle to Late Permian palynoassemblages from southern Gondwana in their generic composition (e.g., Kyle, 1977; Foster, 1979; Kyle and Schopf, 1982; Backhouse, 1991; Farabee et al., 1991; Lindström and McLoughlin, 2007). Basic similarities between the palynofloras of unit $E_{1}$ of the Khunamuh Formation and the latest Permian Protohaploxypinus microcorpus and earliest Triassic Lunatisporites pellucidus palynozones of Australia (Foster, 1982) are evidenced by the shared presence of Crescentipollenites/ Striatopodocarpites and Protohaploxypinus species, Playfordiaspora cancellosa, several lycophyte spore taxa and Reduviasporonites chalastus. Some differences are apparent at species level between these assemblages but these may represent either intra-gondwanan provincialism or alternative approaches to taxonomic appraisal between palynologists from different regions. Significantly, Lunatisporites and lycophytic spores increase in abundance in the latest Permian of Australia and this pattern persists into the Early Triassic (Balme, 1963; Foster, 1982; Helby et al., 1987; Backhouse 1991; Shi et al., 2010). The presence of both of these spore-pollen groups in units $C-E_{1}$ of the Zewan and basal Khunamuh formations supports a stratigraphic position close to the PTB.

The impoverished assemblages from units C-D of the Zewan Formation, containing Crescentipollenites, Protohaploxypinus, Lunatisporites, Verrucosisporites and Alisporites are broadly characteristic of Upper Permian strata of the Karoo Basin, South Africa (Prevec et al., 2009, 2010). The more diverse unit $E_{1}$ palynoassemblage from the Khunamuh Formation contains a range of taxa that were recorded from samples either immediately below or just above the inferred Permian-Triassic boundary in the Balfour Formation of the Karoo Basin (Steiner et al., 2003; Prevec et al., 2010). Significantly, the unit $\mathrm{E}_{1}$ palynoassemblage contains Reduviasporonites and fungal spores - a feature characteristic of samples from just above the palaeomagnetic- and stable-isotopeconstrained PTB in the southern Karoo Basin (Coney et al., 2007). A similar representation of typical latest Permian and earliest Triassic elements, many in common with the unit $\mathrm{E}_{1}$ palynoassemblage but with the notable absence of Reduviasporonites chalastus, occurs at the Lower to Middle Sakamena Group transition in the Morondava Basin, Madagascar (Goubin, 1965; Wright and Askin, 1987). Equivalent associations (hosting Protohaploxypinus, Playfordiaspora, Lundbladispora and Goubinispora species, and in this case, incorporating Reduviasporonites 
chalastus but lacking Lueckisporites and Guttulapollenites) have also been documented from the Maji ya Chumvi Formation in the palaeogeographically adjacent Mombassa Basin of Kenya (Hankel, 1992).

Collectively, the studied palynoassemblages enable broad correlation of the Zewan and lower Khunamuh Formation with units straddling the Permian-Triassic boundary across Gondwana. However, the absence of several species that represent key biostratigraphic markers for the well-resolved latest Permian and earliest Triassic palynozones established in the Australian succession (e.g. Triplexisporites playfordii, Brevitriletes hennellyi, Triquitriletes prorates, Indotriradites rallus, Densoisporites playfordii, Protohaploxypinus microcorpus, Lunatisporites pellucidus, L. acutus, Krauselisporites saeptatus, Lundbladispora obsoleta, Guttulapollenites hannonicus and Limatulasporites limatulus) prevents precise palynological placement of the PTB in the Guryul Ravine Section. $A$ best estimate is that the PTB is within or close to unit $E_{1}$ of the lower Khunamuh Formation.

\subsection{Correlation with the Tethyan-Cathaysian region}

Palynofloras from the Lower Triassic Chinglung Formation at Meishan, east China (Shu and Utting, 1990), from Junggar Basin, northwest China (Shu and Norris, 1999), and Yunnan, south China (Shu, 1982, 1986) share numerous spore-pollen genera with the Khunamuh Formation (unit $\mathrm{E}_{1}$ ) palynoflora, including: Striatopodocarpites, Densipollenites, Protohaploxypinus, Inaperturopollenites, Klausipollenites, Limatulasporites, Lunatisporites, Playfordiaspora, Goubinispora, Lundbladispora and Alisporites. However, the representative spores and pollen generally differ at species level. Further, the palynoflora from Junggar Basin notably includes a large number of genera that are of distinctly Angaran, Euramerican or Cathaysian affinity (Shu and Norris, 1999). Although the shared genera between the Guryul Ravine succession and Cathaysian region offer some opportunities for pan-Tethyan correlation, the differences at species level, which are typical of the strong floristic provincialism at the end of the Palaeozoic (Meyen, 1987), hinders fine correlation over inter-continental scales. Permian-Triassic transitional palynofloras beyond the northern margin of the Tethys (e.g., the Alps, Norway and Greenland) share some genera (e.g., Protohaploxypinus, Taeniaesporites, Klausipollenites, Alisporites, Lunatisporites and Lundbladispora) with the Guryul Ravine succession but include more typically Angaran and Euramerican taxa with increasing remoteness from Gondwana (e.g., Balme, 1980; Visscher and Brugman 1981, 1988; Hochuli et al., 2010a).

\section{Dispersed organic matter}

Apart from recognizable fungi, algae and plant remains (spores; pollen; and plant cuticles and tracheids = phytoclasts; Fig. 6A-E), dispersed organic constituents in the Upper Permian Zewan and Lower Triassic Khunamuh formations can be segregated primarily into amorphous organic matter (AOM; Fig. 6D, J-L), brown degraded organic matter (BDOM; Fig. 6G-I), and opaque (black) organic particles (Fig. 6E, F). The proportions of these constituents can be a useful tool for interpreting the palaeoenvironmental conditions in which the sediments were deposited (Tyson, 1995; Batten, 1996). A caveat on these interpretations is that diagenetic or weathering processes may cause

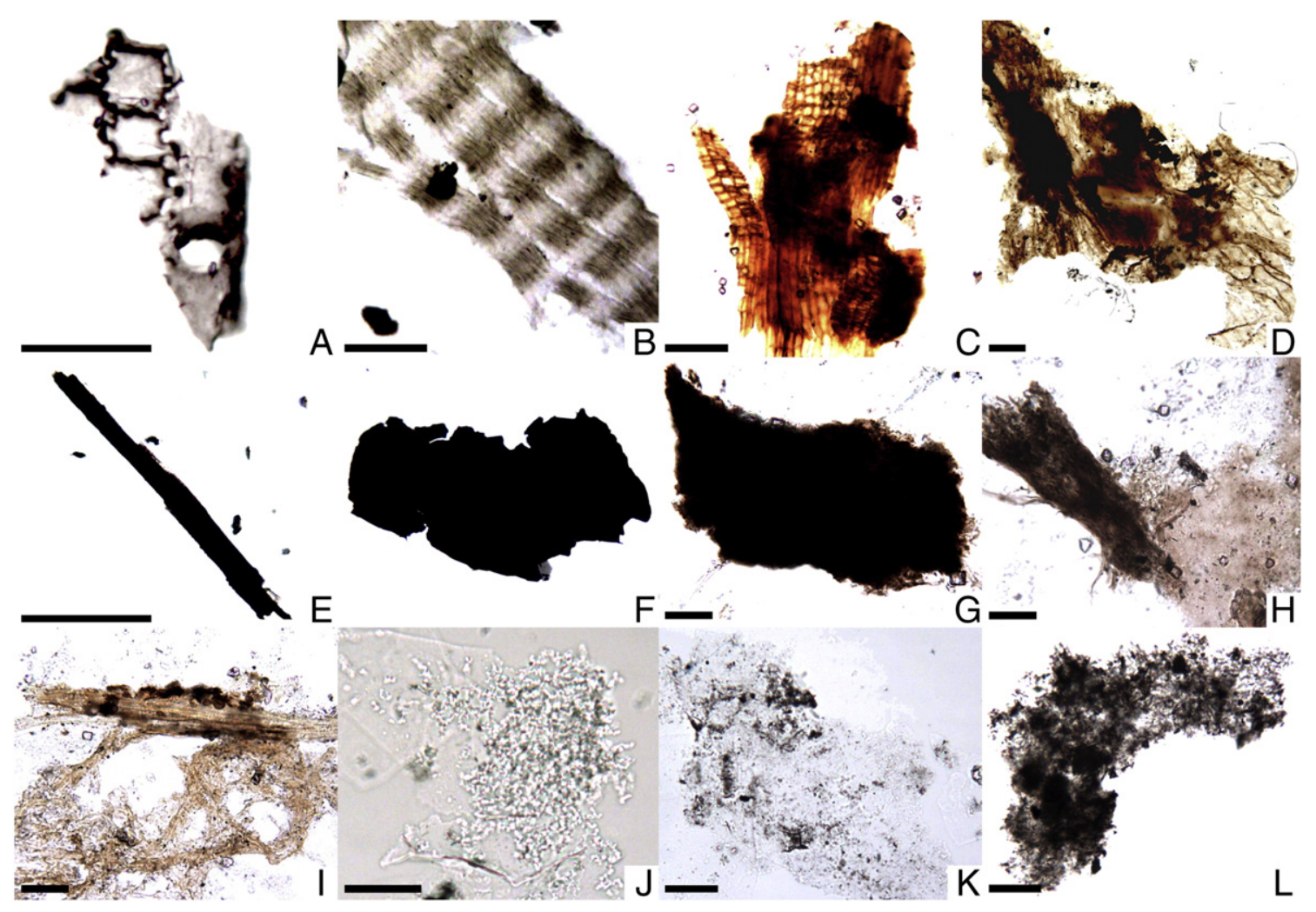

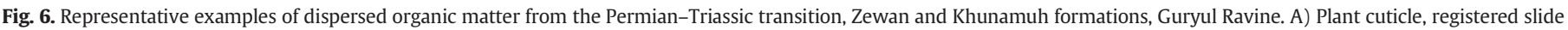

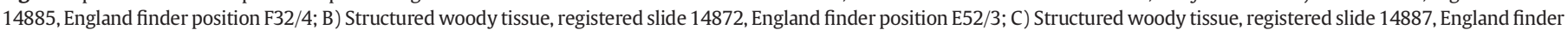

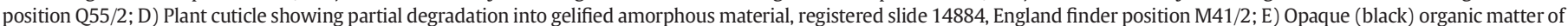

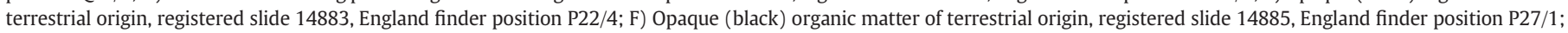

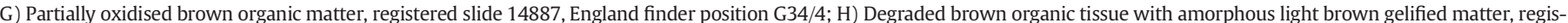

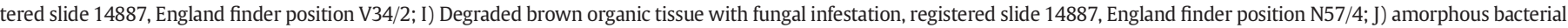

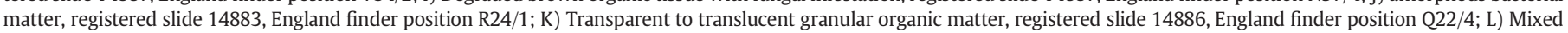
gelified and granular organic matter, registered slide 14883, England finder position N28/3. Scale bars: $20 \mu \mathrm{m}$. 


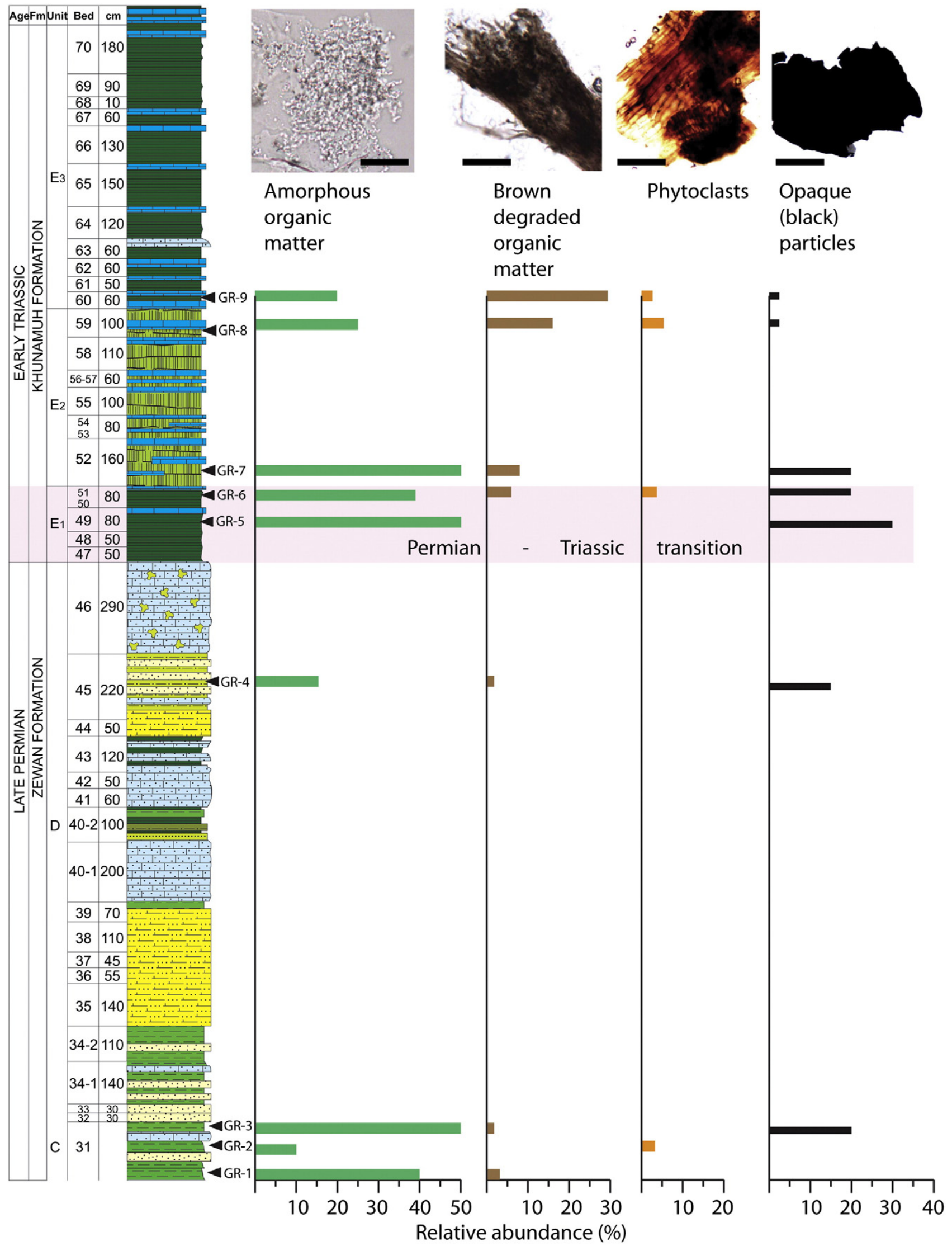

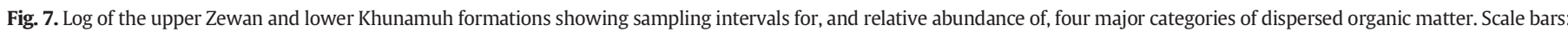
$20 \mu \mathrm{m}$. 
selective degradation of organic matter; and thermal alteration, evidenced by blackening of spores, pollen, and loss of some organic components (Tiwari et al., 1994; Batten, 1996; see Fig. 4E, G, N-Q), which may influence the identification and recognized proportions of phytological constituents within dispersed assemblages.

Of the four samples from the Zewan Formation (GR1-4), AOM is consistently the dominant category of dispersed organic constituents. Opaque (black) organic particles occur in significant quantities in two samples (Fig. 7) but BDOM and phytoclasts are consistently sparse in these samples. These proportions generally indicate a low organic input from terrestrial sources, either from low discharge of river systems or from deterioration of the vegetation cover at the close of the Permian (Retallack et al., 2011, Retallack, 2013). The high AOM content indicates deposition in an oxygen-deficient environment (Mendonça Filho et al., 2010). The AOM in sample GR3 is predominantly granular (Figs. 6K, 7) compared to the low fraction of gelified (Figs. 6H, 7) AOM, reflecting a marine rather than terrestrial origin (Pacton et al., 2011). This interpretation is supported by the absence of freshwater algal remains, which are generally common in continental and paralic palynoassemblages from the Permian (Fielding and McLoughlin, 1992). The AOM preserved in GR4, collected from an argillaceous sandstone unit, is more gelified than granular, suggesting an increased terrestrial contribution.

The five samples (GR5-9) from the Khunamuh Formation show generally decreasing proportions of AOM and opaque (black) organic particles stratigraphically (Fig. 7). There is a corresponding increase in BDOM over the same interval. Phytoclasts represent a consistently low percentage of the organic matter throughout the studied interval. The principal palynoassemblage from unit $\mathrm{E}_{1}$ at the base of the Khunamuh Formation has a relatively high ratio (c. 1.7:1) of saccate to nonsaccate palynomorphs, which is typical of offshore assemblages influenced by taphonomic sorting (Eshet and Cousminer, 1986). Of the amorphous organic components, granular AOM is dominant over gelified AOM in samples GR5 to GR7, whereas the reverse is the case in samples GR8 and GR9. The changes in proportions of the dispersed organic matter categories up section indicate increased terrestrial contributions. However, this may not reflect a genuine shallowing trend given that the proportion of shale and thin limestones increases, and sand content decreases, up section. Further, Brookfield et al. (2003) and Algeo et al. (2007) noted an increase in the benthic diversity in association with these lithological changes and a decrease in storm beds from the Zewan Formation to the Khunamuh Formation that they interpreted to reflect a shift from a shallow storm-influenced shelf to deeper shelf conditions. Hindeodus parvus (conodont) and nektic ammonoids first appear within this transgression (Brookfield et al., 2003) in association with a shift from shallow-water, brachiopod- and bivalve-dominated assemblages to deep-water, ammonoid-rich faunas.

\section{Conclusions}

Palynoassemblages have been recovered for the first time from the uppermost Permian to lowermost Triassic strata of Guryul Ravine, Kashmir-an important regional reference section for the PTB. Although the yield of palynomorphs from this section is low and, in some samples, of poor preservational quality, the assemblages provide sufficient biostratigraphically informative taxa to broadly indicate the position of the PTB around the Zewan Formation to Khunamuh Formation transition. More detailed sampling employing larger sample sizes may provide improved palynostratigraphic resolution in the future. The preliminary results of this study corroborate the placement of the PTB based on the 'mixed' Permian and Triassic faunal elements in unit $\mathrm{E}_{1}$ of the Khunamuh Formation reported by Kapoor (1996) and the strong negative isotope excursion identified at the base of the Khunamuh Formation and correlated with the end-Permian extinction event by Baud et al. (1996) and Algeo et al. (2007). Importantly, the presence in unit $\mathrm{E}_{1}$, albeit in low numbers, of fungal spores and of Reduviasporonites chalastus, an algal or fungal taxon widely reported as a 'disaster species' following the end-Permian mass extinction (Foster et al., 2002; Vajda and McLoughlin, 2007), supports placement of the PTB within or close to this unit. Despite the limitations on yield and preservational quality, the palynoassemblages permit broad correlation with Permian-Triassic transitional sequences along the Tethyan margin of Gondwana and with the well-studied sedimentary successions of basins in peninsular India. Less refined correlations are possible with successions further afield in southern and western Gondwana, and in Cathaysian terranes beyond the Neotethys Ocean. Nevetheless, we consider that this reconnaissance survey provides a valuable starting point for improving correlations between the Gondwanan and Tethyan regions and between continental and marine successions once more intensive sampling is undertaken and where greater consistency is achieved in the taxonomic nomenclature of spore-pollen groups recognized by palynologists from different regions.

The Permian-Triassic transition in Guryul Ravine corresponds to a shift from heterolithic but sand-rich sedimentary packages to a succession dominated by intercalated shales and thin limestones. Although the succession is entirely marine based on its sedimentological signature, acritarchs appear to be absent from the palynoassemblages. Dispersed organic matter assemblages indicate a modest decline in amorphous organic matter, indeterminate opaque particles and the ratio of granular to gelified $\mathrm{AOM}$, and a corresponding increase in degraded brown organic matter near to, or slightly above, the inferred PTB in the Guryul Ravine succession. The distribution of dispersed organic components suggests a slight increase of terrestrial organic constituents through the PTB succession but this contrasts with sedimentological evidence (reduced siliciclastic grain size, increased frequency of shales and thin limestones, and reduction in storm-winnowed beds) and faunal evidence (shift from brachiopod- and bivalve- to nekticammonoid-dominated assemblages) that indicate deepening of the marine depositional environment (Brookfield et al., 2003; Algeo et al., 2007). Local deepening of the depositional setting is also consistent with widely reported occurrences of a marine transgression in other parts of the world in the earliest Triassic (Eshet and Cousminer, 1986; Shu and Utting, 1990; Hallam and Wignall, 1999).

\section{Acknowledgements}

We thank Director, Birbal Sahni Institute of Palaeobotany, Lucknow for providing necessary facilities to carry out the research work. SM acknowledges funding from the Swedish Research Council (VR). We thank two anonymous reviewers whose comments improved the discussion of the results.

\section{References}

Afonin, S.A., Barinova, S.S., Krassilov, V.A., 2001. A bloom of Tympanicysta Balme (green algae of zygnematalean affinities) at the Permian-Triassic boundary. Geologija 23, 481-487.

Ahmad, F., Chib, K.S., Singh, A.J., 1978. Permian system in north and north eastern parts of Kashmir Himalayas. Himal. Geol. 8, 224-251.

Algeo, T., Hannigan, R., Rowe, H., Brookfield, M.E., Baud, A., Krystyn, L., Ellwood, B., 2007. Sequencing events across the Permian-Triassic boundary, Guryul Ravine (Kashmir, India). Palaeogeogr. Palaeoclimatol. Palaeoecol. 252, 328-346.

Alpern, B., 1970. Classification petrographie des constituants organiques fossiles des roches sedimentaires. Revue de I'Institut Francias du pétrole. 25, pp. 1233-1266.

Anderson, J.M., Anderson, H.M., Archangelsky, S., Bamford, M., Chandra, S., Dettmann, M. E., Hill, R.S., McLoughlin, S., Rösler, O., 1999. Patterns of Gondwana plant colonisation and diversification. Afr. J. Earth Sci. 28, 145-167.

Backhouse, J., 1991. Permian palynostratigraphy of the Collie Basin, Western Australia. Rev. Palaeobot. Palynol. 67, 237-314.

Bakker, R.T., 1977. Tetrapod mass extinctions-a model of the regulation of speciation rates and immigration by cycles of topographic diversity. In: Hallam, A. (Ed.), Patterns of evolution, as illustrated by the fossil record. Elsevier, Amsterdam, pp. 439-468.

Balme, B.E., 1963. Plant microfossils from the Lower Triassic of Western Australia. Palaeontology 6, 12-40. 
Balme, B.E., 1970. Palynology of Permian and Triassic strata in the Salt Range and Surghar Range, West Pakistan. In: Kummel, B., Teichert, C. (Eds.), Stratigraphic boundary problems: Permian and Triassic of West Pakistan 4. University Press of Kansas, Department of Geology Special Publication, Kansas, pp. 306-453.

Balme, B.E., 1980. Palynology of Permian-Triassic boundary beds of Kap Stosch, East Greenland. Meddelelser om Grønland. 200, pp. 1-35.

Basu, A.R., Petaev, M.I., Poreda, R.J., Jacobsen, S.B., Becker, L., 2003. Chondritic meteorite fragments associated with the Permian-Triassic boundary in Antarctica. Science 302, 1388-1392.

Batten, D.J., 1983. Identification of amorphous sedimentary organic matter by transmitted light microscopy. In: Brooks, J. (Ed.), Petroleum and exploration in Europe. Blackwell Science Publication, Oxford, pp. 275-287.

Batten, D.J., 1996. Chapter 26A. Palynofacies and palaeoenvironmental interpretation. In: Jansonius, J., Mc Gregor, D.C. (Eds.), Palynology: principles and applications vol. 3. American Association of Stratigraphic Palynologists Foundation, College Station, Texas, pp. 1011-1064.

Baud, A., Atudorei, V., Sharp, Z., 1996. Late Permian and Early Triassic evolution of the Northern Indian margin: carbon isotope and sequence stratigraphy. Acta Geodyn. 9, 57-77.

Becker, L., Poreda, R.J., Basu, A.R., Pope, K.O., Harrison, T.M., Nicholson, C., Iasky, R., 2004. Bedout: a possible end-Permian impact crater offshore of northwestern Australia. Science 304, 1469-1476.

Benton, M.J., Newell, A.J., 2014. Impacts of global warming on Permo-Triassic terrestrial ecosystems. Gondwana Res. 25, 1308-1337.

Benton, M.J., Twitchett, R.J., 2003. How to kill (almost) all life: the end-Permian extinction event. Trends Ecol. Evol. 18, 358-365.

Beurlen, K., 1956. Der Faunenschnitt an der Perm-Trias Grenze. Z. Dtsch. Geol. Ges. 108, 88-99.

Bhat, G.M., Bhat, G.D., 1997. Stratigraphy and depositional environments of Late Permian carbonates, Kashmir Himalaya. In: Wijayananda, N.P., Cooray, P.G., Mosley, P. (Eds.), Geology in South Asia - IIProfessional paper 7. Geological Survey and Mines Bureau, Sri Lanka, pp. 205-223.

Bourquin, S., Bercovici, A., López-Gómez, J., Diez, J.B., Broutin, J., Ronchi, A., Durand, M. Arche, A., Linol, B., Amour, F., 2011. The Permian-Triassic transition and the onset of Mesozoic sedimentation at the northwestern peri-Tethyan domain scale: Palaeogeographic maps and geodynamic implications. Palaeogeogr. Palaeoclimatol. Palaeoecol. 299, 265-280

Boussafir, M., Gelin, F., Lallier-Verges, E., Derenne, S., Bertrand, P., Largeau, C., 1995. Electron microscopy and pyrolysis of kerogens from the Kimmeridge Clay Formation, UK: source organisms, preservation processes and origin of microcycles. Geochim. Cosmochim. Acta 59, 3731-3847.

Brookfield, M.E., 1993. The Himalayan passive margin from Precambrian to Cretaceous times. Sediment. Geol. 84, 1-35.

Brookfield, M.E., Twitchett, R.J., Goodings, C., 2003. Palaeoenvironments of the PermianTriassic transition sections in Kashmir, India. Palaeogeogr. Palaeoclimatol. Palaeoecol. 198, 353-371.

Brookfield, M.E., Shellnutt, J.G., Qi, L., Hannigan, R., Bhat, G.M., Wignall, P.B., 2010. Platinum element group variations at the Permo-Triassic boundary in Kashmir and British Columbia and their significance. Chem. Geol. 272, 12-19.

Cloud Jr., P.E., 1959. Paleoecology-retrospect and prospect. J. Paleontol. 33, 926-962.

Collinson, J.W., Hammer, W.R., Askin, R.A., Elliot, D.H., 2006. Permian-Triassic boundary in the central Transantarctic Mountains, Antarctica. Geol. Soc. Am. Bull. 118, 747-763.

Combaz, A., 1964. Les palynofaciès. Rev. Micropaleontol. 7, 205-218.

Coney, L., Reimold, W.U., Hancox, P.J., Mader, D., Koeberl, C., McDonald, I., Struck, U. Vajda, V., Kamo, S.L., 2007. Geochemical and mineralogical investigation of the Permian-Triassic boundary in the continental realm of the southern Karoo Basin, South Africa. Palaeoworld 16, 67-104

Ercegovac, M., Kostic, A., 2006. Organic facies and palynofacies: Nomenclature, classification and applicability for petroleum source rock evaluation. Int. J. Coal Geol. 68, 70-78.

Erwin, D.H., 1993. The Great Paleozoic Crisis. Columbia University Press, New York (257 pp.).

Eshet, Y., 1992. The palynofloral succession and palynological events in the Permo-Triassic boundary interval in Israel. In: Sweet, W.C., Yang, Z., Dickins, J.M., Yin, H. (Eds.), Permo-triassic events in the eastern Tethys. Cambridge University Press, Cambridge, pp. 134-145

Eshet, Y., Cousminer, H.L., 1986. Palynozonation and correlation of the Permo-Triassic succession in southern Israel. Micropaleontology 32, 193-214.

Eshet, Y., Rampino, M., Visscher, H., 1995. Fungal event and palynological record of ecological crisis and recovery across the Permian-Triassic boundary. Geology 23, 967-970.

Farabee, M.J., Taylor, E.L., Taylor, T.N., 1990. Correlation of Permian and Triassic palynomorph assemblages from the central Transantarctic Mountains, Antarctica. Rev. Palaeobot. Palynol. 65, 257-265.

Farabee, M.J., Taylor, E.L., Taylor, T.N., 1991. Late Permian palynomorphs from the Buckley Formation, central Transantarctic Mountains, Antarctica. Rev. Palaeobot. Palynol. 69, 353-368.

Feistmantel, O., 1879. The fossil flora of the Gondwana system, Chapter I - The flora of the Talchir-Karharbari beds. Palaeontol. Ind. Ser. 12 (3), 1-48.

Fielding, C.R., McLoughlin, S., 1992. Sedimentology and palynostratigraphy of Permian rocks exposed at Fairbairn Dam, central Queensland. Aust. J. Earth Sci. 39, 631-649.

Foster, C.B., 1979. Permian plant microfossils of the Blair Athol Coal Measures and basal Rewan Formation of Queensland. Geological Survey of Queensland Publications. 372, pp. $1-244$.

Foster, C.B., 1982. Spore-pollen assemblages of the Bowen Basin, Queensland (Australia): their relationship to the Permian/Triassic boundary. Rev. Palaeobot. Palynol. 36, $165-183$.
Foster, C.B., 1983. Review of the time frame for the Permian of Queensland. In: anonymous (Ed.), Permian Geology of Queensland. Geological Society of Australia, Queensland Division, Brisbane, pp. 107-120.

Foster, C.B., Stephenson, M.H., Marshall, C., Logan, G.A., Greenwood, P.F., 2002. A revision of Reduviasporonites Wilson 1962: description, illustration, comparison and biological affinities. Palynology 26, 35-58.

Furnish, W.M., Glenister, B.F., Nakazawa, K., Kapoor, H.M., 1973. Permian ammonoid Cyclolobus from the Zewan Formation, Guryul Ravine, Kashmir. Science 180, 188-190.

Goubin, N., 1965. Description et répartition des principaux pollenites Permiens, Triasiques et Jurassiques des sondages du Basin de Morondava (Madagascar). Revue de l'Institut Francais du pétrole. 20, pp. 1415-1461.

Habib, D., 1982. Sedimentary supply origin of Cretaceous black-shales. In: Schlanger, S.O. Cita, M.B. (Eds.), Nature and origin of cretaceous carbon-rich facies. Academic Press, London, pp. 113-127.

Hallam, A., Wignall, P.B., 1999. Mass extinctions and sea-level changes. Earth Sci. Rev. 48, $217-250$.

Hankel, O., 1992. Late Permian to Early Triassic microfloral assemblages from the Mayiya Chumvi Formation, Kenya. Rev. Palaeobot. Palynol. 72, 129-147.

Hansen, H.J., 2006. Stable isotopes of carbon from basaltic rocks and their possible relation to atmospheric isotope excursions. Lithos 92, 105-116.

Harrowfield, M., Holdgate, G., Wilson, C., McLoughlin, S., 2005. Tectonic significance of the Lambert Graben, East Antarctica: reconstructing the Gondwanan rift. Geology 33, 197-200.

Hart, G.F., 1986. Origin and classification of organic matter in clastic systems. Palynology $10,1-23$.

Hatfield, C.B., Camp, M.J., 1970. Mass extinctions correlated with periodic galactic events Bull. Geol. Soc. Am. 81, 911-914.

Hayden, H.H., 1907. The stratigraphical position of the Gangamopteris beds of Kashmir. Rec. Geol. Surv. India 36, 23-39.

Helby, R., Morgan, R., Partridge, A.D., 1987. A palynological zonation of the Australian Mesozoic. Assoc. Australas. Paleontol. Mem. 4, 1-85.

Hill, R.S., Truswell, E.M., McLoughlin, S., Dettmann, M.E., 1999. The evolution of the Australian flora: fossil evidence. In: Orchard, A.E. (Ed.), Flora of Australia, 2nd Edition, 1 (Introduction). CSIRO, Melbourne, pp. 251-320.

Hochuli, P.A., Vigran, J.O., Hermann, E., Bucher, H., 2010a. Multiple climatic changes around the Permian-Triassic boundary event revealed by an expanded palynological record from mid-Norway. Geol. Soc. Am. Bull. 122, 884-896.

Hochuli, P.A., Hermann, E., Vigran, J.O., Bucher, H., Weissert, H., 2010b. Rapid demise and recovery of plant ecosystems across the end-Permian extinction event. Glob. Planet. Chang. 74, 144-155.

Hüssner, V.H., 1983. Die Faunenwende Perm/Trias. Geol. Rundsch. 72, 1-22.

Jha, N., Aggarwal, N., 2012. Permian-Triassic palynostratigraphy in Mailaram area, Godavari Graben, Andhra Pradesh, India. J. Earth Sci. Syst. Sci. 121, 1257-1285.

Jha, N., Chary, M.B., Aggarwal, N., 2012. Permian-Triassic palynofloral transition in Chintalapudi area, Godavari Graben, Andhra Pradesh, India. J. Earth.Syst. Sci. 121, 1287-1303.

Kaiho, K., Kajiwara, Y., Nakano, T., Miura, Y., Kawahata, H., Tazaki, K., Ueshima, M., Chen, Z Q., Shi, G.R., 2001. End-Permian catastrophe by a bolide impact: evidence of a gigantic release of sulphur from the mantle. Geology 29, 815-818.

Kapoor, H.M., 1977. Pastannah section of Kashmir with special reference to 'Ophioceras' bed of Middlemiss. J. Palaeontol. Soc. India 20, 339-347.

Kapoor, H.M., 1979. Gondwana of Kashmir - a reappraisal. In: Laskar, B., Raja Rao, C.S (Eds.), Proceedings of the Fourth International Gondwana Symposium, Calcutta 1977 vol. 2. Hindustan Publishing Corporation, Delhi, pp. 443-462.

Kapoor, H.M., 1996. The Guryul ravine section, candidate of the global stratotype and point (GSSP) of the Permian-Triassic boundary (PTB). In: Yin, H. (Ed.), The Paleozoic-Mesozoic boundary: candidates of the global stratotype section and point of the Permian-Triassic boundary. China University Geosciences Press, Wuhan, pp. 99-110.

Knoll, A.H., Bambach, R.K., Canfield, D.E., Grotzinger, J.P., 1996. Comparative earth history and Late Permian mass extinction. Science 273, 452-457.

Korte, C., Pande, P., Kalia, P., Kozur, H.W., Joachimski, M.M., Oberhansli, H., 2010. Massive volcanism at the Permian-Triassic boundary and its impact on the isotopic composition of the ocean and atmosphere. J. Asian Earth Sci. 37, 293-311.

Kyle, R.A., 1977. Palynostratigraphy in the Victoria Group of South Victoria Land Antarctica. N. Z. J. Geol. Geophys. 10, 1081-1102.

Kyle, R.A., Schopf, J.M., 1982. Permian and Triassic palynostratigraphy of the Victoria Group, Transantarctic Mountains. In: Craddock, C. (Ed.), Antarctic geosciences. University of Wisconsin Press, Madison, WI, pp. 649-659.

Lindström, S., 1995. Early Late Permian palynostratigraphy and palaeo-biogeography of Vestfjella, Dronning Maud Land, Antarctica. Rev. Palaeobot. Palynol. 86, 157-173.

Lindström, S., McLoughlin, S., 2007. Synchronous palynofloristic extinction and recovery after the end-Permian event in the Prince Charles Mountains, Antarctica: implications for palynofloristic turnover across Gondwana. Rev. Palaeobot. Palynol. 145, 89-122.

Lindström, S., McLoughlin, S., Drinnan, A.N., 1997. Intraspecific variation of taeniate bisaccate pollen within Permian glossopterid sporangia, from the Prince Charles Mountains, Antarctica. Int. J. Plant Sci. 158, 673-684.

Lydekker, R., 1883. The geology of Kashmir and Chambe territories and British District of Khagan. Geol. Surv. india Mem. 22, 1-344.

Maheshwari, H.K., Kapoor, H.M., Bajpai, U., 1996. Permian plant mega and palynofossils from Gondwana-equivalent sediments of Kashmir Valley. Palaeobotanist 43, $145-150$.

Masran, T.C., Pocock, S.A.J., 1981. The classification of plant-derived particulate organic matter in sedimentary rocks. In: Brooks, J. (Ed.), Organic maturation studies and fossil fuel exploration. Academic Press, London, pp. 145-175. 
Matsuda, T., 1981a. Early Triassic conodonts from Kashmir, India, Part 1. Hindeodus and Isarcicella. J. Geosci. Osaka City Univ. 23, 75-100.

Matsuda, T., 1981b. Appendix to conodonts of Guryul Ravine. Palaeontologia indica, new series. 46 , pp. $187-188$.

Matsuda, T., 1983. Early Triassic conodonts from Kashmir, India. Part 3: Neospathodus 2. J. Geosci. Osaka City Univ. 26, 87-110.

Matsuda, T., 1984. Early Triassic conodonts from Kashmir, India, Part 4: Gondolella and Platyvillosus. J. Geosci. Osaka City Univ. 27, 119-141.

Maxwell, W.D., 1989. The end Permian mass extinction. In: Donovan, S.K. (Ed.), Mass extinctions: process and evidence. Belhaven Press, London, p. 259.

McLoughlin, S., 2011. Glossopteris - insights into the architecture and relationships of an iconic Permian Gondwanan plant. J. Asiat. Soc. Bengal 65, 93-106.

McLoughlin, S., Lindström, S., Drinnan, A.N., 1997. Gondwanan floristic and sedimentological trends during the Permian-Triassic transition: new evidence from the Amery Group, northern Prince Charles Mountains, East Antarctica. Antarct. Sci. 9, 281-298.

Mendonça Filho, J.G., Menezes, T.R., Mendonça, J.O., Oliveira, A.D., Carvalho, M.A., Sant'Anna, A.J., Souza, J.T., 2010. Palinofácies. In: Carvalho, I.S. (Ed.), Paleontologia 3 vol. 2. Interciência, Rio de Janeiro, pp. 379-413.

Metcalfe, I., 1999. The ancient Tethys oceans of Asia: How many? How old? How deep? How wide? UNEAC Asia Papers. 1, pp. 1-9.

Meyen, S.V., 1987. Fundamentals of Palaeobotany. Chapman and Hall, London (432 pp.)

Middlemiss, C.S., 1909. Gondwanas and related marine sedimentary systems of Kashmir. Rec. Geol. Surv.India 37, 286-327.

Middlemiss, C.S., 1910. A revision of the Silurian-Trias sequence in Kashmir. Rec. Geol. Surv. India 40, 206-260.

Murata, M., 1981. Permian and Triassic condonts from Guryul Ravine. Palaeontologia indica, new series. 46, pp. 179-186

Nakazawa, K., 1977. On Claraia of Kashmir and Iran. J. Palaeontol. Soc. India 20, 191-204

Nakazawa, K., 1992. The Permian and Triassic Boundary. Albertina. 10, pp. 23-30.

Nakazawa, K., Kapoor, H.M., 1977. Correlation of the marine Permian in the Tethys and Gondwana. In: Laskar, B., Raja Rao, C.S. (Eds.), Proceedings of the Fourth International Gondwana Symposium, Calcutta 1977 vol. 1. Hindustan Publishing Corporation, Delhi, pp. 409-419.

Nakazawa, K., Kapoor, H.M., 1981. The Upper Permian and Lower Triassic Faunas of Kashmir. Palaeontologia indica new series. 46, pp. 1-191.

Nakazawa, K., Kapoor, H.M., Ihii, Y., Bando, T., Maegoya, D., Shimizu, D., Nogami, T. Tokuoka, T., Nohda, S., 1970. Preliminary report on the Permo-Trias of Kashmir, India. Memoirs of the Faculty of Science, Kyoto University, Series of Geology and Mineralogy, Kyoto. 37, pp. 163-172.

Nakazawa, K., Kapoor, H.M., Ishii, K., Bando, Y., Okimura, Y., Tokuoka, T., 1975. The Upper Permian and Lower Triassic in Kashmir, India. Memoirs of the Faculty of Science. 42. Kyoto University, Series of Geology and Mineralogy, Kyoto, pp. 1-106.

Nautiyal, A.C., Sahni, A., 1976. Lower Triassic argillaceous sequence of Pahalgam (Kashmir) and palynological observations. Proceedings of the Indian National Science Academy. 42A, pp. 364-371.

Newell, N.D., 1963. Crises in the history of life. Sci. Am. 208, 76-92.

Okimura, Y., Ishii, K., 1981. Upper Permian and Lower Triassic Foraminifera from Guryul Ravine and the Spur three kilometres north of Barus. Palaeontologia indica new series. 46 , pp. 23-40.

Pacton, M., Gorin, G., Vasconcelos, C. 2011. Amorphous organic matter - Experimenta data on formation and the role of microbes. Rev. Palaeobot. Palynol. 166, 253-267.

Peng, Y., Yu, J., Gao, Y., Yang, F., 2006. Palynological assemblages of non-marine rocks at the Permian-Triassic boundary, western Guizhou and eastern Yunnan, South China. J. Asian Earth Sci. 28, 291-305.

Prevec, R., Labandeira, C.C., Neveling, J., Gastaldo, R.A., Looy, C.V., Bamford, M., 2009. Portrait of a Gondwanan ecosystem: A new late Permian fossil locality from KwaZuluNatal, South Africa. Rev. Palaeobot. Palynol. 156, 454-493.

Prevec, R., Gastaldo, R.A., Neveling, J., Reid, S.B., Looy, C.V., 2010. An autochthonous glossopterid flora with latest Permian palynomorphs and its depositional setting in the Dicynodon Assemblage Zone of the southern Karoo Basin, South Africa. Palaeogeogr. Palaeoclimatol. Palaeoecol. 292, 391-408.

Ram-Awatar, 1993. Palynological dating of sub-surface sequence of Middle Pali Member in Sohagpur Coalfield (M.P.), India. Geophytology 23, 107-114.

Ram-Awatar, 2011. Late Permian palynofossils from the ammonoid bearing bed from Gungri Formation, Spiti Valley, Tethys Himalaya, India. World Conference on Palaeontology and Stratigraphy, Nakhon, Ratchasima, Thailand.

Reichow, M.K., Pringle, M.S., Al'Mukhamedov, A.I., Allen, M.B., Andreichev, V.L., Buslov, M. M., Davies, C.E., Fedoseev, G.S., Fitton, J.G., Inger, S., Medvedev, A.Ya., Mitchell, C., Puchkov, V.N., Safonova, I.Yu., Scott, R.A., Saunders, A.D., 2009. The timing and extent of the eruption of the Siberian Traps large igneous province: Implications for the endPermian environmental crisis. Earth Planet. Sci. Lett. 277, 9-20.

Renne, P.R., Zheng, Z.C., Richards, M.A., Black, M.T., Basu, A.R., 1995. Synchrony and causal relations between Permian-Triassic boundary crisis and Siberian flood volcanism. Science 269, 1413-1416

Retallack, G.J., 2013. Permian and Triassic greenhouse crises. Gondwana Res. 24, 90-103.

Retallack, G.J., Sheldon, N.D., Carr, P.F., Fanning, M., Thompson, C.A., Williams, M.L., Jones, B. G., Hutton, A., 2011. Multiple early Triassic greenhouse crises impeded recovery from late Permian mass extinction. Palaeogeogr. Palaeoclimatol. Palaeoecol. 308, 233-251.

Robert, P., 1981. Classification of organic matter by means of fluorescence; application to hydrocarbon source rocks. Int. J. Coal Geol. 1, 101-137.

Schneebeli-Hermann, E., Kürschner, W.M., Kerp, H., Bomfleur, B., Hochuli, P.A., Bucher, H., Ware, D., Roohi, G., 2014s. Vegetation history across the Permian-Triassic boundary in Pakistan (Amb section, Salt Range). Gondwana Res. http://dx.doi.org/10.1016/j. gr.2013.11.007 (In press).

Schulte, P., 40 others, 2010. The Chicxulub asteroid impact and mass extinction at the Cretaceous-Paleogene boundary. Science 327, 1214-1218.
Scotese, C.R., 1997. Paleogeographic atlas. PALEOMAP Progress Report 90-0497. Department of Geology, University of Texas at Arlington, Arlington, Texas, pp. 1-45.

Sengör, A.M.C., 1984. The Cimmeride orogenic system and the tectonics of Eurasia. Geol. Soc. Am. Spec. Pap. 195, 1-82.

Sheng, J., Chen, C., Wang, Y., Rui, L., Liao, Z., Dando, Y., Ishii, K., Nakazawa, K., Nakamura, K., 1984. Permian-Triassic boundary in middle and eastern Tethys. J. Fac. Sci. Hokkaido Univ 21 (1), 133-181.

Shi, G.R., Waterhouse, J.B., McLoughlin, S., 2010. The Lopingian of Australasia: a review of biostratigraphy, correlations, palaeogeography and palaeobiogeography. Geol. J. 45, 230-263.

Shu, O., 1982. Upper Permian and Lower Triassic palynomorphs from eastern Yunnan, China. Can. J. Earth Sci. 19, 68-80.

Shu, O., 1986. The assemblage of Late Permian-Early Triassic in Fuyuan Yunnan Province. Science Press, Beijing (122 pp).

Shu, O., Norris, G., 1999. Earliest Triassic (Induan) spores and pollen from the Junggar Basin, Xinjiang, northwest China. Rev. Palaeobot. Palynol. 106, 1-56.

Shu, O., Utting, J., 1990. Palynology of upper Permian and lower Triassic rocks, Meishan, Changxing County, Zheijiang Province, China. Rev. Palaeobot. Palynol. 66, 65-103.

Singh, G., Maithy, P.K., Bose, M.N., 1982. Upper Palaeozoic flora of Kashmir Himalaya. Palaeobotanist 30, 185-232.

Singh, T., Tiwari, R.S., Vijaya, Ram Awatar, 1995. Stratigraphy and palynology of Carboniferous-Permian-Triassic succession in Spiti Valley, Tethyan Himalaya, India. J. Palaeontol. Soc. India 40, 55-76.

Stanley, S.M., 1984. Marine mass extinctions: a dominant role for temperature. In: Nitecki, M.H. (Ed.), Exinctions. University of Chicago Press, Chicago, pp. 69-117.

Stanley, S.M., 1988. Palaeozoic mass extinctions: shared patterns suggest global cooling as a common cause. Am. J. Sci. 288, 334-352.

Steiner, M.B., Eshet, Y., Rampino, M.R., Schwindt, D.M., 2003. Fungal abundance spike and the Permian-Triassic boundary in the Karoo Supergroup (South Africa). Palaeogeogr. Palaeoclimatol. Palaeoecol. 194, 405-414.

Stevens, C.H., 1977. Was development of brackish oceans a factor in Permian extinctions? Geol. Soc. Am. Bull. 88, 133-138.

Stolle, E., 2007. Regional Permian palynological correlations: southeast Turkey - northern Iraq. Compt. Rendus Geosci. 94, 125-143.

Sweet, W.C., 1970. Permian and Triassic conodonts from a section at Guryul Ravine, Vihi district, Kashmir. Univ. Kansas Palaeontol. Contrib. 49, 1-10.

Teichert, C., Kummell, B., Kapoor, H.M., 1970. Mixed Permian-Triassic fauna, Guryul Ravine, Kashmir. Science 167, 175-176.

Tiwari, R.S., 1997. Palynological changes at Permian-Triassic transition in Tethyan sequence of Himalaya in Spiti Valley, Himachal Pradesh and Niti region, Uttar Pradesh, India. Gondwana Geol. Mag. 12, 1-14.

Tiwari, R.S., 1999. Paradigm of FAD, LAD and DOD of some miospore taxa in Late Permian and Early Triassic successions on the Indian Peninsula. J. Palaeontol. Soc. India 44, 69-89.

Tiwari, R.S., Singh, Vijaya, 1986. Palynological evidences for Permo-Triassic boundary in Raniganj Coalfield, Damodar Basin, India. Bull. Geol. Min. Metall. Soc. India 54, 256-264.

Tiwari, R.S., Tripathi, A., 1992. Marker assemblage zones of spore and pollen species through Gondwana Palaeozoic-Mesozoic sequence in India. Palaeobotanist 40, 194-236.

Tiwari, R.S., Vijaya, 1992. Permo-Triassic boundary on the Indian peninsula. In: Sweet, W. C., Yang, Z., Dickins, J.M., Yin, H., Sweet, W.C., Yang, Z., Dickins, J.M., Yin, H. (Eds.), Permo-Triassic events in the Eastern Tethys. Cambridge University Press, Cambridge, pp. 37-45.

Tiwari, R.S., Vijaya, 1994. Synchroneity of palynological events and patterns of extinction at Permo-Triassic boundary in terrestrial sequence of India. In: Guex, J., Baud, A. (Eds.), Recent developments in Triassic stratigraphy. Mémoires de géologie. 22, pp. 139-154 (Lausanne)

Tiwari, R.S., Singh, V., Kumar, S., Singh, I.B., Singh, S.K., 1980. Gondwana plant microfossils from the Tethyan sediments, Malla Johar Area, Uttar Pradesh. J. Palaeontol. Soc. India 23 (24), 39-42.

Tiwari, R.S., Singh, V., Kumar, S., Singh, I.B., 1984. Palynological studies of the Tethyan sequence in Malla Johar area, Kumaon Himalaya, India. Palaeobotanist 32, 341-367.

Tiwari, R.S., Vijaya, Mishra, B.K., 1994. Taphonomy of spores and pollen in Gondwana sequence of India. Palaeobotanist 42, 108-119.

Tiwari, R.S., Vijaya, Mamgain, V.D., Misra, R.S., 1996. Palynological studies on a Late Palaeozoic-Mesozoic Tethyan sequence in the Niti area of the Central Himalaya, Uttar Pradesh, India. Rev. Palaeobot. Palynol. 94, 169-196.

Tripathi, A., 2001. Palynological expression about Permian-Triassic transition in the Talcher Coalfield, Orissa, India. Palaeobotanist 50, 247-253.

Tripathi, A., Vijaya, Raychowdhari, A.K., 2005. Triassic palynoflora from the MahuliMahersop area, Singrauli Coalfield (southern extension), Sarguja District, Chhatisgarh, India. J. Palaeontol. Soc. India 50, 77-99.

Twitchett, R.J., 2006. The palaeoclimatology, palaeoecology and palaeoenvironmental analysis of mass extinction events. Palaeogeogr. Palaeoclimatol. Palaeoecol. 232, 190-213.

Tyson, R.V., 1995. Sedimentary organic matter; organic facies and palynofacies. Chapman and Hall, London (615 pp.).

Vajda, V., McLoughlin, S., 2007. Extinction and recovery patterns of the vegetation across Cretaceous-Palaeogene boundary - a tool for unravelling the causes of the endPermian mass-extinction. Rev. Palaeobot. Palynol. 144, 99-112.

van Bergen, P.F., Janssen, N.M., Alferink, M., Kerp, J.H.F., 1990. Recognition of organic matter types in standard palynological slides. In: Fermont, J.J., Weegink, J.W. (Eds.), International symposium on organic petrology. Mededelingen rijks geologische dienst. 45, pp. 9-21. 
Visscher, H., Brugman, W.A., 1981. Ranges of selected palynomorphs in the Alpine Triassic of Europe. Rev. Palaeobot. Palynol. 34, 115-128.

Visscher, H., Brugman, W.A., 1988. The Permian-Triassic boundary in Southern Alps: A palynological approach. Mem. Soc. Geol. Ital. 34, 121-128.

Wignall, P.B., Hallam, A., 1992. Anoxia as a cause of the Permian/Triassic mass extinction: facies evidence from northern Italy and the western United States. Palaeogeogr. Palaeoclimatol. Palaeoecol. 93, 21-46.

Wignall, P.B., Twitchett, R.J., 1996. Oceanic anoxia and the end Permian mass extinction. Science 272, 1155-1158.
Wright, R.P., Askin, R.A., 1987. The Permian Triassic boundary in the southern Morondava Basin of Madagascar as defined by plant microfossils. Am. Geophys. Union Monogr 41, 157-166.

Yin, H., 1993. A proposal for the gloal stratotype section and point (GSSP) of the PermianTriassic boundary, the Chinese working group on the Permian-Triassic boundary Albertiana 11, 4-40.

Yin, H., Kexin, Z., Jinnan, T., Zunyi, Y., Shunbao, W., 2001. The Global Stratotype Section and Point (GSSP) of the Permian-Triassic Boundary. Episodes 24, 102-114. 